\title{
Estudio de la situación de precipitaciones intensas de los días 22 y 23 de octubre de 2015 en Canarias
}

NOTA TÉCNICA 22 DE AEMET

David Quintero Plaza ${ }^{1}$ y David Suárez Molina²

${ }^{1}$ Técnico superior de meteorología CMT Canarias Oriental (AEMET)

${ }^{2}$ Grupo de Predicción y Vigilancia de Canarias (GPV) (AEMET) 
Aviso Legal: los contenidos de esta publicación podrán ser reutilizados, citando la fuente y la fecha, en su caso, de la última actualización

\section{Edita:}

(c) Ministerio de Agricultura, Alimentación y Medio Ambiente Agencia Estatal de Meteorología

Madrid, 2016

Catálogo de Publicaciones de la Administración General del Estado: https://cpage.mpr.gob.es

NIPO: $281-16-008-9$

https://doi.org/10.31978/281-16-008-9

Agencia Estatal de Meteorología (AEMET)

$\mathrm{C} /$ Leonardo Prieto Castro, 8

28040 Madrid

http://www.aemet.es/

@Aemet_Esp

https://www.facebook.com/AgenciaEstataldeMeteorologia 


\section{Índice}

1. Resumen.

2. Descripción de la situación y registros. 2

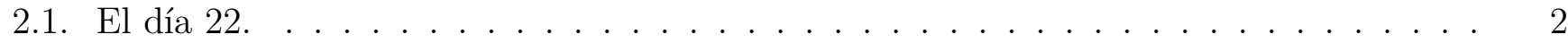

2.1.1. Entorno sinóptico y mesoescalar. . . . . . . . . . . . . . . . . . 3

2.1.2. Análisis de sondeos. . . . . . . . . . . . . . . . . . . 7

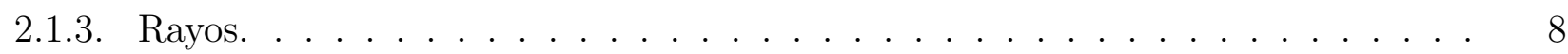

2.1.4. Radar. . . . . . . . . . . . . . . . . . . . 11

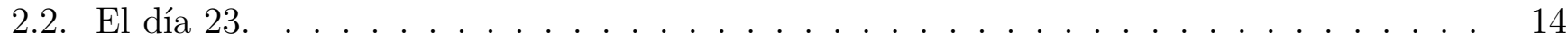

2.2.1. Entorno sinóptico y mesoescalar. . . . . . . . . . . . . . . . . . . 14

2.2.2. Análisis de sondeos. . . . . . . . . . . . . . . . . . . 15

2.2.3. Rayos. . . . . . . . . . . . . . . . . . . . . . . . . . . . . . . . . . . . . . . . .

2.2.4. Radar. . . . . . . . . . . . . . . . . . . . . 21

3. Análisis de comportamiento de los modelos. 21

3.1. El día 22. . . . . . . . . . . . . . . . . . . . . . . . . . . . 22

3.1.1. El modelo del Centro Europeo. . . . . . . . . . . . . . . . . . . . . . 22

3.1.2. El modelo Harmonie. . . . . . . . . . . . . . . . . . . . . . . . . 25

3.2. El día 23. . . . . . . . . . . . . . . . . . . . . . . . . . . . . . . . 25

3.2.1. El modelo del Centro Europeo. . . . . . . . . . . . . . . . . . 25

3.2.2. El modelo Harmonie. . . . . . . . . . . . . . . . . . . . . . . . . . . . 26

4. Conclusiones. $\quad 32$

5. Agradecimientos. 33

6. Acrónimos. 33

$\begin{array}{ll}\text { 7. Bibliografía. } & 34\end{array}$ 


\section{Resumen.}

Durante los días 22 y 23 de octubre de 2015 las islas Canarias se vieron afectadas por fenómenos meteorógicos adversos debidos a precipitaciones fuertes (entre 15 y $30 \mathrm{~mm} / \mathrm{h}$ ) a muy fuertes $(30$ a $60 \mathrm{~mm} / \mathrm{h}$ ) sin descartar que en algún punto fueran incluso torrenciales (más de $60 \mathrm{~mm} / \mathrm{h}$ ). Estas precipitaciones intensas estaban ligadas a un entorno favorable para el desarrollo de la convección debido a una gran baja con dos máximos de vorticidad principales, uno al noroeste de Canarias, asociado a una baja con algunas características tropicales y otro al nordeste, con vaguada y anomalía fría de $-14^{\circ} \mathrm{C}$.

La isla más afectada fue Gran Canaria y concretamente los municipios del norte y este, como la capital, Las Palmas de Gran Canaria, y Telde. Se produjeron numerosos daños materiales: inundaciones de centros comerciales, riadas, corte de las principales autovías y túneles que unen los distintos municipios con la capital de la isla, suspensión de la docencia en los centros educativos de todos los niveles y además se observó una tromba marina en Maspalomas, hecho que llegó a estar recogido en el sistema Sinobas de AEMET.

Veremos que a pesar de la mejora de la resolución espacial y temporal de los modelos, estos no son capaces de pronosticar fenómenos locales, es decir, afectados por la orografía real de las islas, con lo que la figura del predictor experimentado y con conocimiento del área es de suma importancia.

Palabras clave: precipitaciones, convección, tropical, orografía, modelos.

\section{Descripción de la situación y registros.}

El mes de octubre de 2015 fue especialmente agitado en cuanto a precipitación se refiere en Canarias. No es de sorprender dado que el otoño ha dejado ya en varias ocasiones fenómenos de importancia [Martín et al., 2006] y es en general una estación en la que los registros son altos [AEMET, 2016]. Nosotros nos centraremos en dos días en concreto, el 22 y el 23 de octubre, en los que se llegaron a superar los 100 litros por metro cuadrado.

La predicción de este tipo de situaciones de precipitaciones intensas en Canarias es un reto importante, debido a la compleja orografía de las islas, la limitada resolución espacial de los modelos numéricos de predicción (tanto en la horizontal como en la vertical), además de tener en cuenta que tal vez las precipitaciones pueden ocurrir en el mar, muy cerca de las islas, pero evidentemente sin consecuencias para la población, quedando sin aparente efecto tanto avisos como boletines. Si a todo esto sumamos que puedan tener lugar precipitaciones súbitas de carácter muy fuerte o torrenciales en zonas puntuales o locales, la predicción de situaciones como las que nos atañe, en un desafío de suma complejidad.

\subsection{El día 22 .}

Las dificultades antes mencionadas se aprecian en los boletines y avisos emitidos por el GPV de Canarias para el día 22. Según los boletines se esperaban precipitaciones localmente fuertes (15 a $30 \mathrm{~mm} / \mathrm{h}$ ) en la mitad occidental del archipiélago (La Palma, El Hierro, La Gomera y Tenerife) acompañadas de tormentas. En cambio, la situación que iba a afectar a las islas orientales (Gran Canaria, Lanzarote y Fuerteventura) no estaba tan clara.

La secuencia de la emisión de los avisos para este día fue la siguente:

- Durante la mañana del día 21 se emite aviso amarillo por precipitaciones fuertes en una hora (P1) en las islas occidentales.

- A últimas horas de la tarde se modifica y se incluye el resto de islas.

- A primeras horas de la mañana del día 22 y gracias a las importantes tareas de vigilancia y contacto telefónico con varios colaboradores de la zona de Telde, se nos informa de que se han 


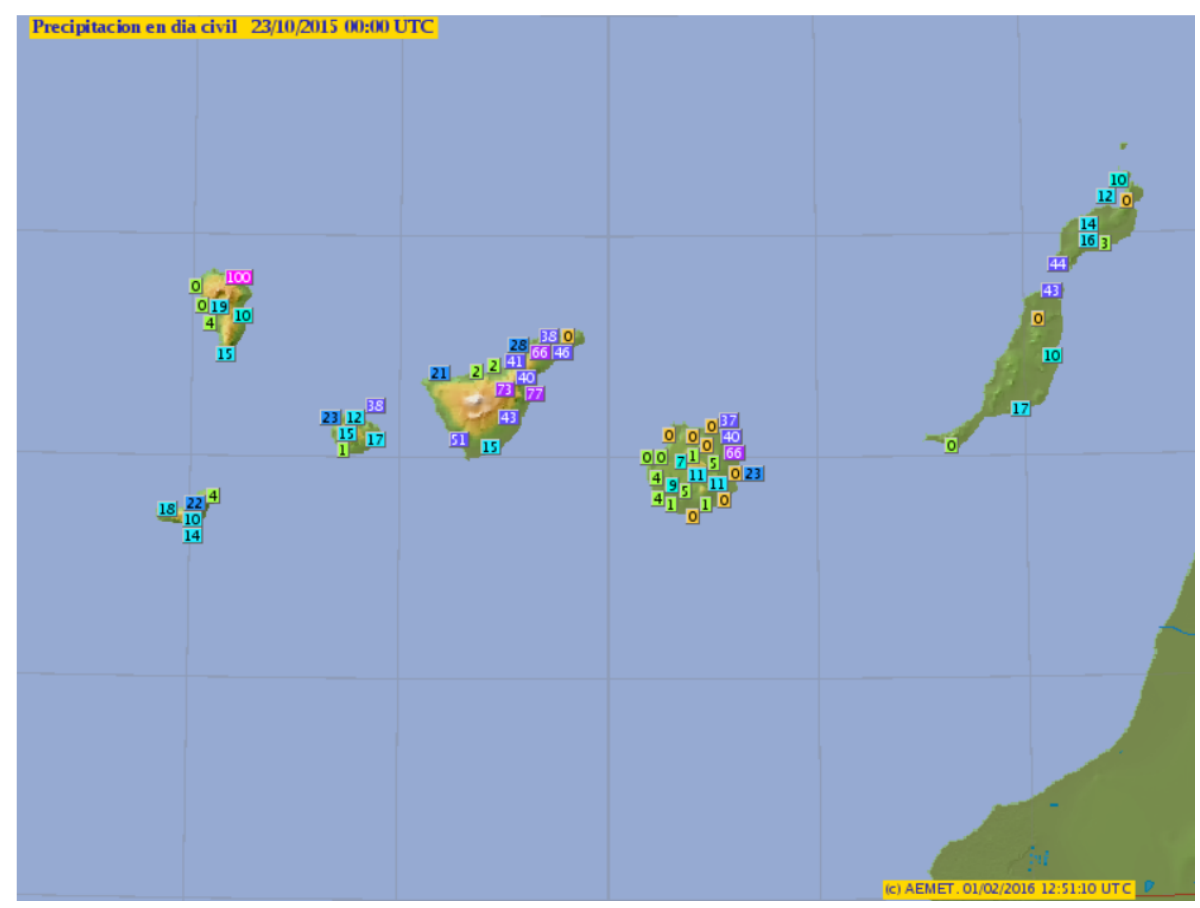

Figura 1: Estaciones, precipitación en las 24 horas anteriores del día 22.

registrado precipitaciones muy fuertes y/o torrenciales en dicha zona de la isla de Gran Canaria y se procede a emitir un aviso observado de nivel naranja.

En la figura (1) se muestran los avisos emitidos la mañana del complicado día 22. También podemos ver en la figura (2) los datos de precipitación de las estaciones automáticas de la red de AEMET.

\subsubsection{Entorno sinóptico y mesoescalar.}

La presencia de una baja al oeste del archipiélago (figura 3) es siempre motivo de especial cuidado a la hora de los pronósticos. Aunque, como es el caso, no sea una baja demasiado profunda, supone un elemento que inestabiliza la atmósfera y además, por su ubicación, inyecta un continuo aire cálido y húmedo, de características tropicales, sobre el archipiélago. Siempre se ha dicho, entre los predictores del GPV de Canarias, que las situaciones de sur son las que peor tienden a captar los modelos y son las que requieren un cuidado más especial.

La guía de diagnóstico de niveles medios y altos mostraba a las 00 UTC dos chorros circundando el archipiélago y un máximo de vorticidad que a partir de las 12 UTC se tradujo en unos máximos de mayor importancia así como de un alejamiento del chorro del nordeste, seguido de un claro reforzamiento (aparición de un segundo chorro, de hecho) de los chorros del suroeste sobre las islas (figuras 4, 5).

Como se puede también ver en la imagen de McIdas (figura 6), en niveles altos hay una DANA (que al día siguiente se convirtió en vaguada), reflejo de la baja en superficie (o vicecersa). El máximo de vorticidad potencial es muy claro en este aspecto. La DANA hacía que en principio toda la zona geográfica afectada por ella tuviera potencial convectivo severo [Martín León, 2002]. 


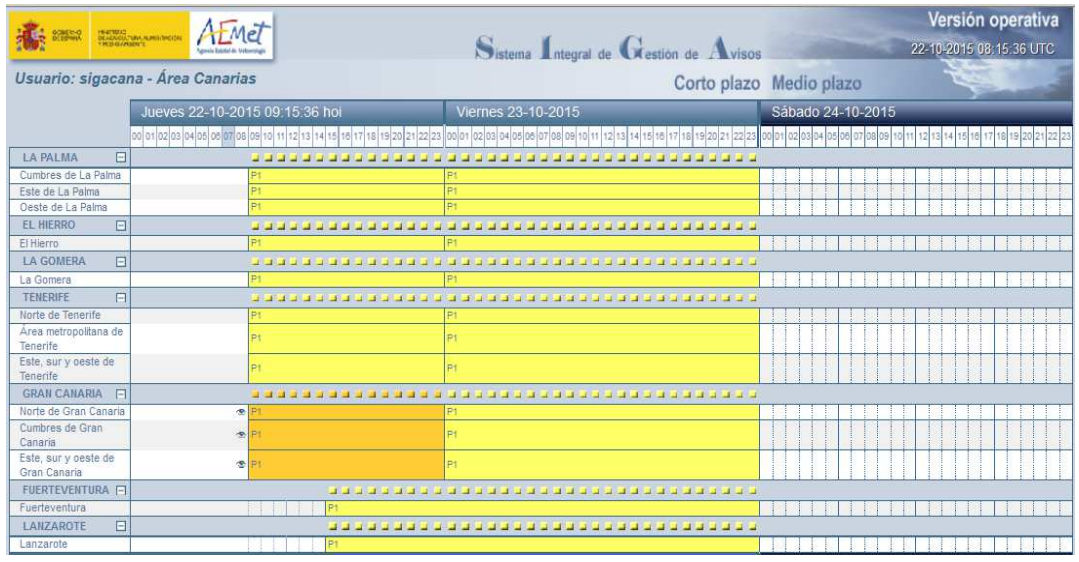

Avisos válidos a las 09:20 hora local canaria del día 22 de octubre de 2015 Los avisos se actualizarán siguiendo la evolución de la situación

Abreviaturas: P1=Precipitación acumulada en 1 hora; P2=Precipitación acumulada en 12 horas; $\mathrm{RM}=$ Racha máxima de viento; TO=Tormenta; TA=Temperatura máxima; TI=Temperatura mínima; $\mathrm{CO}=$ Fenómeno costero significativo; $\mathrm{VI}$ : Visibilidad reducida por polvo; $\mathrm{NI}=\mathrm{Visibilidad}$ reducida por niebla; $\mathrm{NV}=\mathrm{Nevada}$

Figura 2: Avisos del día 22 de octubre de 2015.

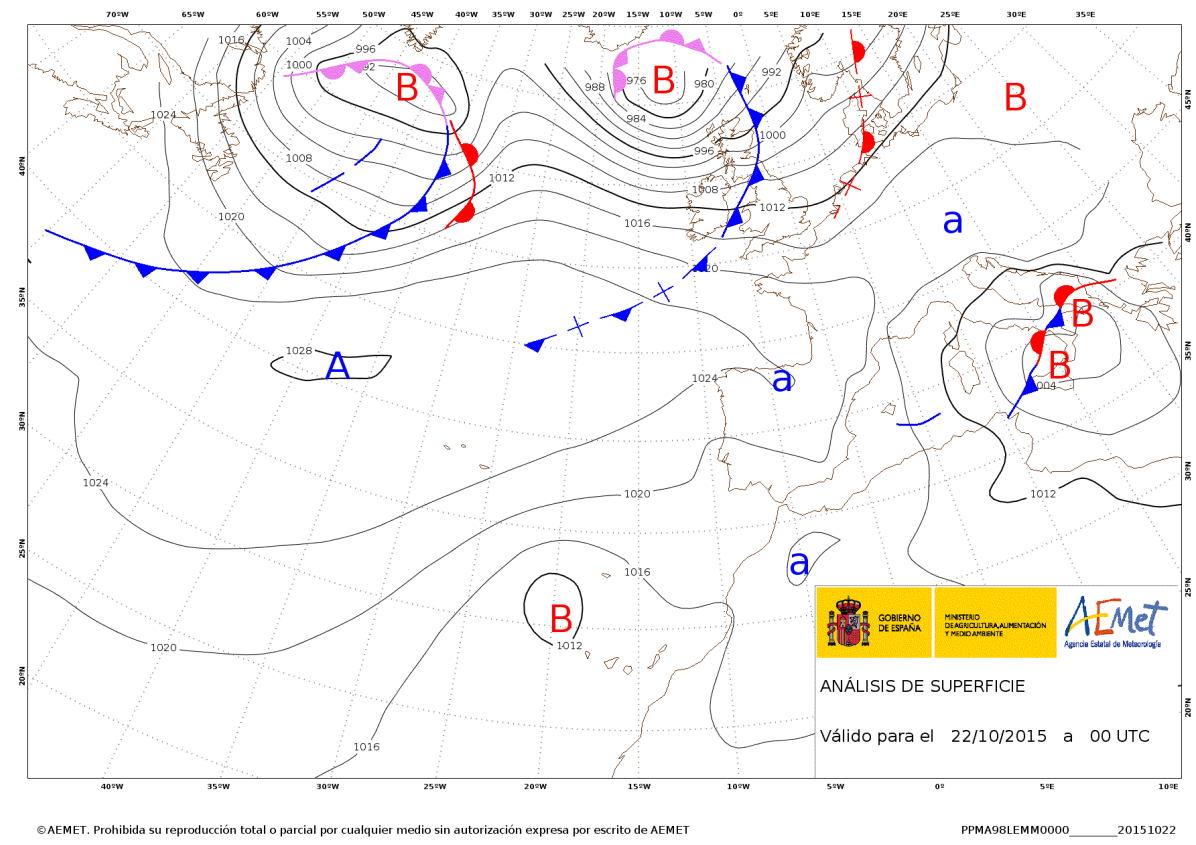

Figura 3: Análisis de superficie del día 22 de octubre de 2015 las 00 UTC. 


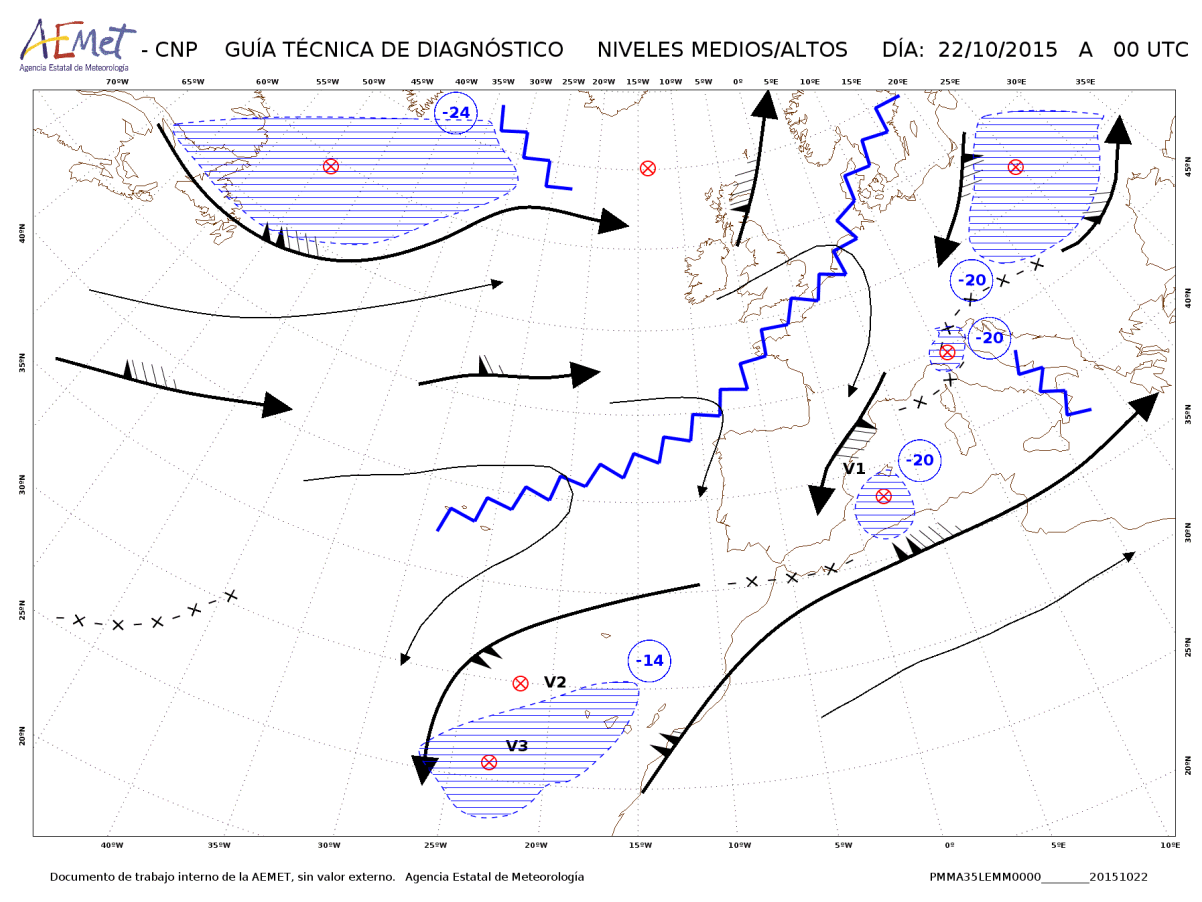

Figura 4: Guía de diagnóstico de niveles medios y altos del 22 a las 00.

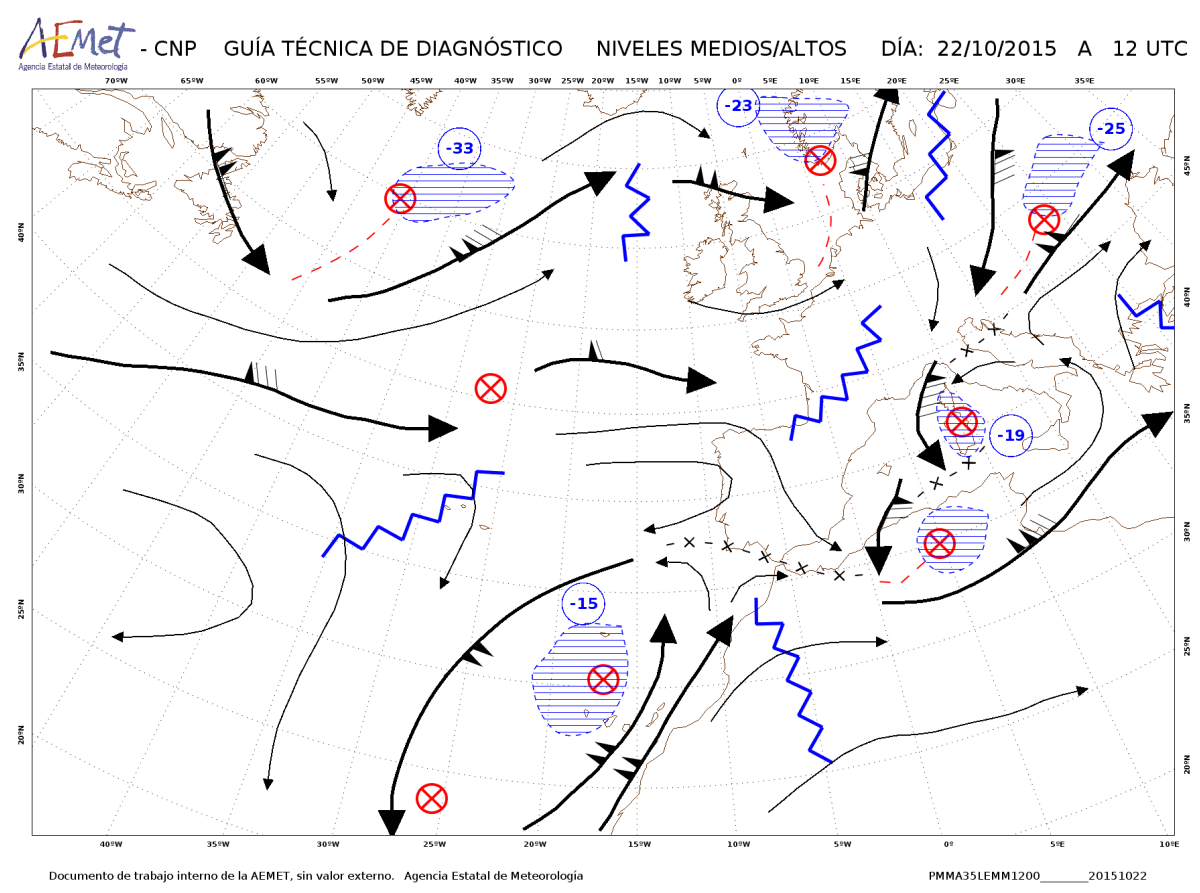

Figura 5: Guía de diagnóstico de niveles medios y altos del 22 a las 12 . 


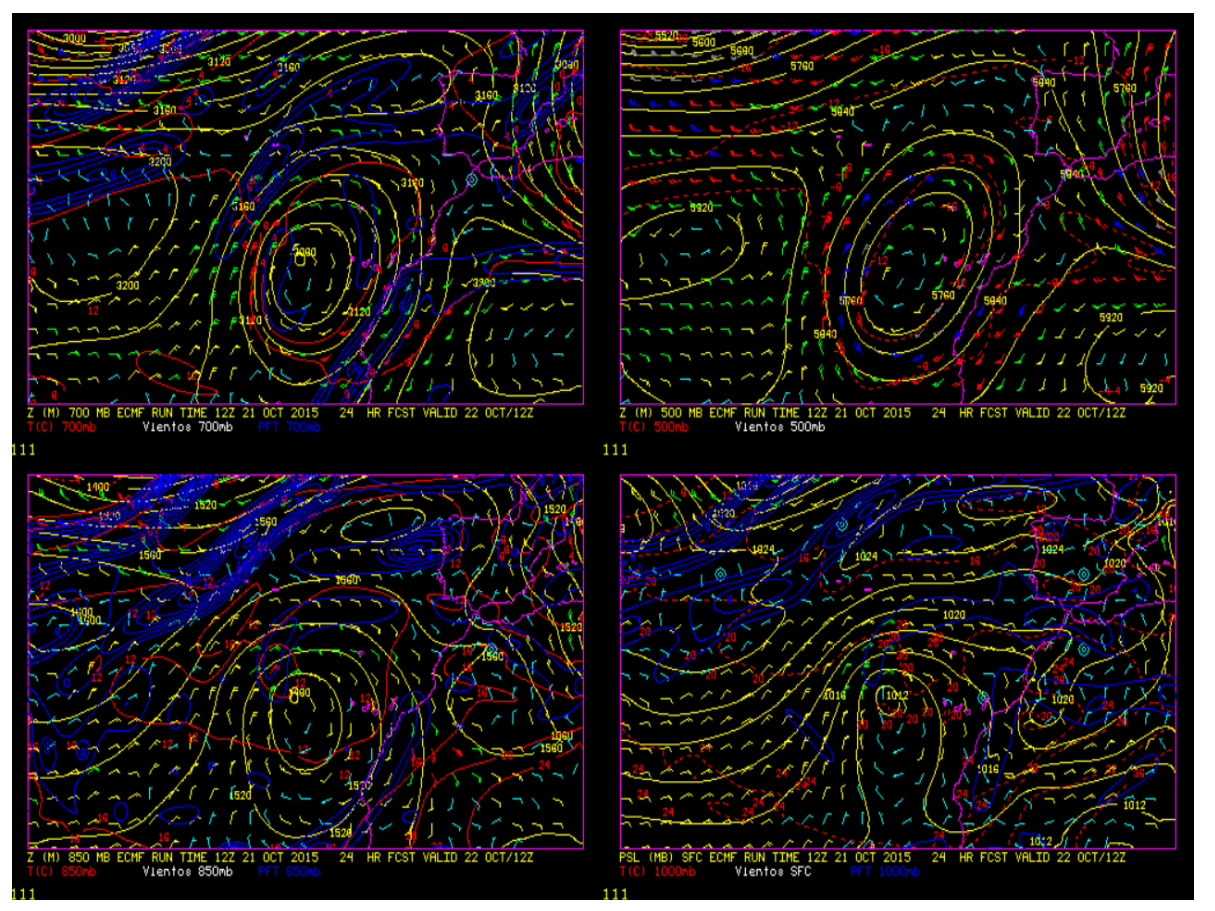

Figura 6: Situación sinóptica del día 22 a las 12. 


\subsubsection{Análisis de sondeos.}

Se dispone de los datos obtenidos por el radiosondeo meteorológico realizado en Güímar (zona este de Tenerife) a las 00 y 12 UTC. En ambos perfiles (figuras 7, 8) se observa cómo el flujo en toda la vertical de la atmósfera era de dirección suroeste y aumentando de intensidad con la altura, presentando una cizalladura unidireccional. La cizalladura en el sondeo de las 12UTC entre SFC-1km fue de $3.10 \mathrm{~m} / \mathrm{s}$,entre SFC-3 km de $6.17 \mathrm{~m} / \mathrm{s}$ y entre SFC-6km de $9.77 \mathrm{~m} / \mathrm{s}$. Como vemos, la cizalladura de niveles bajos (SFC-1km) está muy por debajo del umbral de $10 \mathrm{~m} / \mathrm{s}$ típico de tornados significativos (umbral utilizado en Estados Unidos), aunque valores entre 3 a $5 \mathrm{~m} / \mathrm{s}$ son observados en situaciones de tormentas; en cambio la cizalladura entre SFC-6km está muy próxima a los $10 \mathrm{~m} / \mathrm{s}$, valor que aparece como posible umbral más bajo de tormentas severas, estando, eso sí, lejos de los umbrales utilizados para clasificar como supercélulas o tornados severos (18 a 20 m/s) [Craven y Brooks, 2004]. La helicidad relativa de la tormenta ( $\mathrm{SRH}$ en adelante), es una medida potencial de la rotación ciclónica de la corriente ascendente y ha sido calculada hasta el primer y tercer kilómetro sobre el nivel del suelo. En este caso los valores fueron, entre SFC- $1 \mathrm{~km}$ de $22 \mathrm{~m}^{2} / \mathrm{s}^{2}$ y entre SFC-3km de 44 $\mathrm{m}^{2} / \mathrm{s}^{2}$. No existen valores umbrales claros, pero los obtenidos por este sondeo están lejos de los usados para clasificar supercélulas tornádicas (mayores a 100 ó $250 \mathrm{~m}^{2} / \mathrm{s}^{2}$ respectivamente) [NOAA, 2016].

La inestabilidad o gradiente vertical (lapse rate) entre $0-3 \mathrm{~km}$ fue de $6.5^{\circ} \mathrm{C} / \mathrm{km}$ y entre 700 $500 \mathrm{hPa}$ de $6.4^{\circ} \mathrm{C} / \mathrm{km}$ (atmósfera condicionalmente inestable). Como referencia, un típico gradiente vertical adiabático húmedo es $5^{\circ} \mathrm{C} / \mathrm{km}$, un gradiente vertical de la atmśofera estándar es de $6.5^{\circ} \mathrm{C} / \mathrm{km}$ (desde 0 a $6 \mathrm{~km}$ ) mientrás que el adiabático seco es de $9.8^{\circ} \mathrm{C} / \mathrm{km}$. Los valores de gradiente vertical entre 0-3 km de situaciones de tormentas, tormentas severas, eventos de granizo y viento significativo tienen un valor medio de $7.5^{\circ} \mathrm{C} / \mathrm{km}$, en cambio el 75 por ciento de los tornados se dan con valores inferiores a esos $7.5^{\circ} \mathrm{C} / \mathrm{km}$ [Craven y Brooks, 2004]. Para el gradiente vertical de niveles medios (700$500 \mathrm{hPa}$ ), los eventos de tormentas, tormentas severas, granizo y tornados se dan con valores entre 6 a $7.5^{\circ} \mathrm{C} / \mathrm{km}$. [Doswell et al., 1985] discutieron la importancia del gradiente vertical entre 700-500 hPa para la creación de una fuerte inestabilidad condicional y para el realce de la respuesta de la atmósfera al forzamiento cuasi-geostrófico.

Ambos sondeos ponen de manifiesto la evolución temporal de las condiciones en el entorno de interés y podemos destacar el aumento en la intensidad del viento desde las 00 UTC hasta las 12 UTC partiendo desde niveles bajos $(925 \mathrm{hPa}$ ) hasta niveles medios y altos. Llaman la atención los 45 nudos (unos $81 \mathrm{~km} / \mathrm{h}$ ) en $850 \mathrm{hPa}$ (alrededor de 1500 metros) afectando este viento muy fuerte a la compleja orografía de las zonas de cumbres de las islas.

Por otro lado, la inversión térmica de $2.8^{\circ} \mathrm{C}$ del sondeo de las 00 UTC, partiendo desde el nivel del suelo (105 metros, altura a la cual está situada la localidad donde se realiza el radiosondeo) debida al enfriamiento radiativo nocturno y que actúa de tapadera inhibiendo la convección, desapareció en el sondeo de las 12 UTC, favoreciendo esto el desarrollo vertical de los núcleos convectivos.

Uno de los ingredientes más importantes en situaciones de este tipo es la evolución temporal de la humedad en el entorno. Se observa a simple vista el aumento (desde las 00 UTC hasta las 12 UTC) de este parámetro en los radiosondeos, permaneciendo la atmósfera con valores de humedad relativa por encima del 80 por ciento desde el suelo hasta el nivel de $585 \mathrm{hPa}$ (en gran parte de este amplio estrato vertical se registraron valores del cien por cien) y por encima de $448 \mathrm{hPa}$ hasta $395 \mathrm{hPa}$. El aislamiento de la depresión en niveles altos y posicionamiento al oeste del archipiélago inyectó un continuo flujo del suroeste cálido y húmedo sobre las islas aumentando como hemos visto anteriormente la humedad en toda la vertical.

Los datos obtenidos en los radiosondeos muestran una evidente inestabilización de la atmósfera circundante, y una clara muestra de esto son los cambios registrados en los índices clásicos de inestabilidad, como ocurrió con el índice Lifted (pasando de 1.60 a $-1.68^{\circ} \mathrm{C}$ ), índice $\mathrm{K}$ (pasando de 24.40 a 33.70), total de totales (47.50 a 48.20) o Energía Potencial Convectiva Disponible (CAPE) (incremento desde 0 a $451.68 \mathrm{~J} / \mathrm{kg}$ ). El contenido en agua precipitable también aumentó de forma 


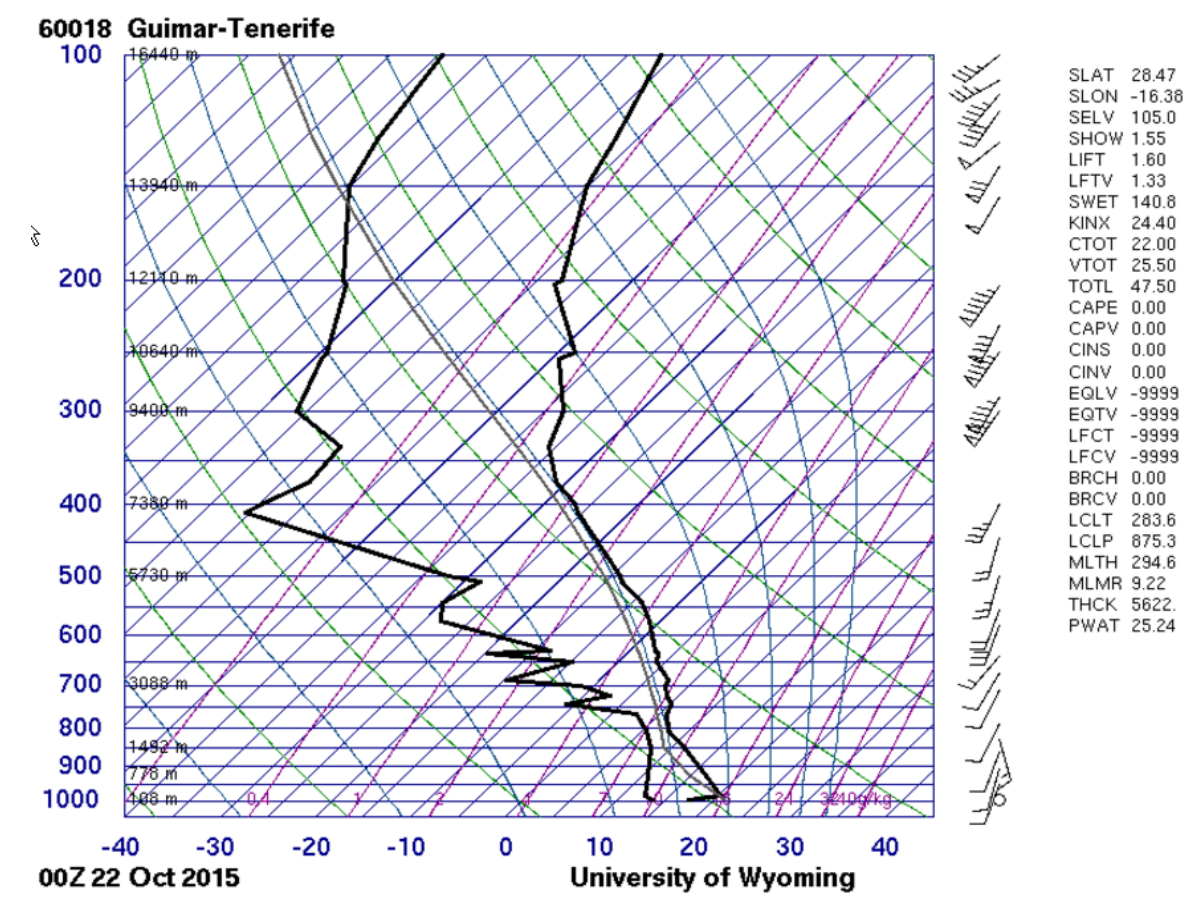

Figura 7: Radiosondeo del día 22 de octubre de 2015 de las 00 UTC sobre Güímar (Tenerife).

considerable desde las 00 UTC $(25.24 \mathrm{~mm})$ hasta las 12 UTC $(37.73 \mathrm{~mm})$ señal de una masa tropical cálida.

Centrando la atención en el radiosondeo de las 12 UTC (figura 8) se observa que el nivel de condensación por ascenso (NCA) se situó a 430 metros, el nivel de condensación libre (NCL) a 952 metros y el nivel de equilibrio (NE) a 9310 metros. Por un lado vemos que el nivel teórico de las bases de las nubes (marcado por el NCA) y el NCL eran inferiores a 1000 metros (bastante bajos) y también podemos estimar que la altura del yunque de las tormentas podría alcanzar la altura del NE. Una escasa diferencia NCA-NCL suele indicar probable convección profunda.

\subsubsection{Rayos.}

En la figura (9) se presenta la actividad eléctrica nube-tierra (NT) registrada por los detectores de AEMET durante el día 22. Hemos representado los datos para el área de la Subzona Islas perteneciente al FIR de Canarias. Se registraron 2117 rayos en las 24 horas, de los cuales 1833 fueron rayos negativos y 284 rayos positivos.

La inmensa mayoría de las descargas se registraron en el mar y principalmente al norte del archipiélago, coincidiendo con la zona de mayor inestabilidad, asociada con el escudo convectivo de la DANA situada al oeste-suroeste de las islas.

Es llamativo observar que en la isla de Gran Canaria, a pesar de las repentinas e intensas precipitaciones registradas durante la mañana de este día, estas no estaban acompañadas de aparato eléctrico. En las islas occidentales sí se registraron puntuales descargas, principalmente en Tenerife. Las descargas que afectaron a esta isla están relacionadas con una estructura en forma de presunta línea de turbonada (esta estructura se discutirá en el siguente apartado), que se desarrolló a partir de las 10 UTC con orientación suroeste-nordeste generando las precipitaciones más importantes registradas este día en Tenerife (figura 10). Esta estructura se disipó en torno a las 20 UTC. 


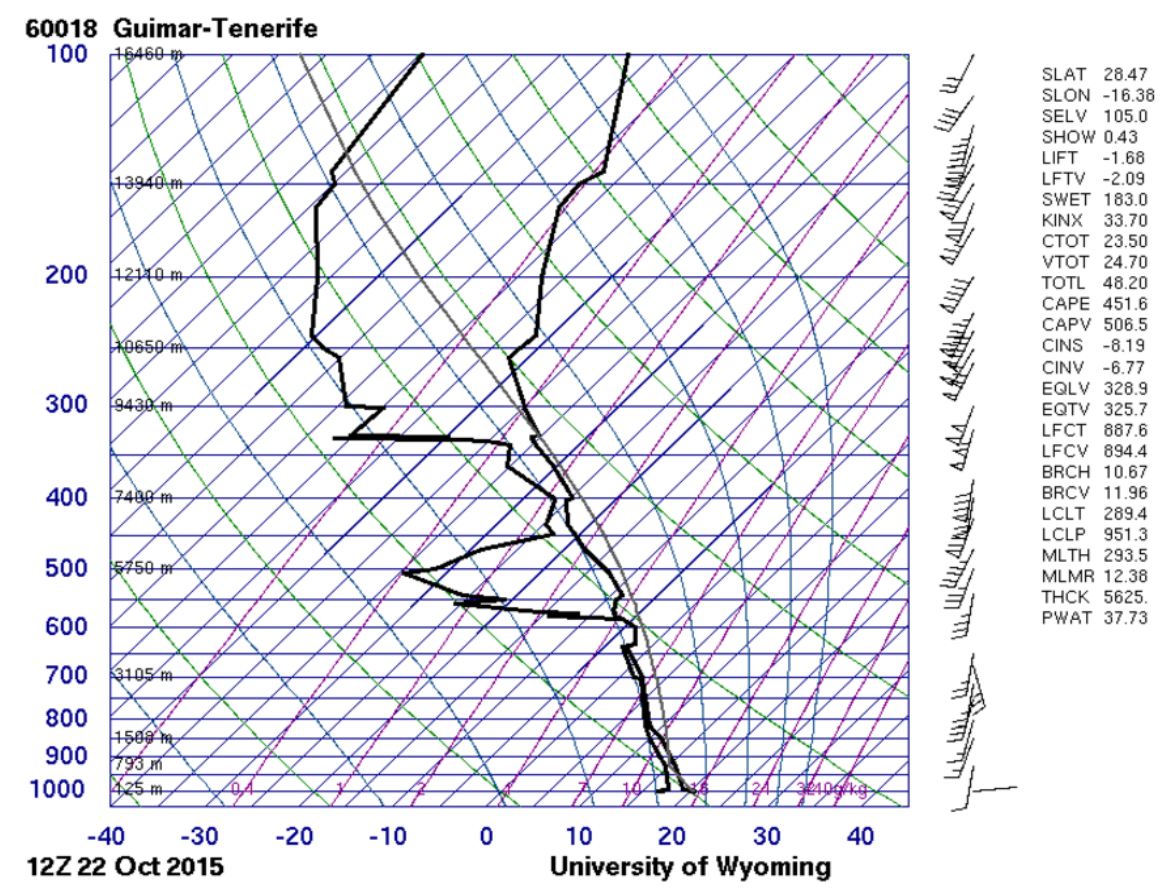

Figura 8: Radiosondeo del día 22 de octubre de 2015 de las 12 UTC sobre Güímar (Tenerife).

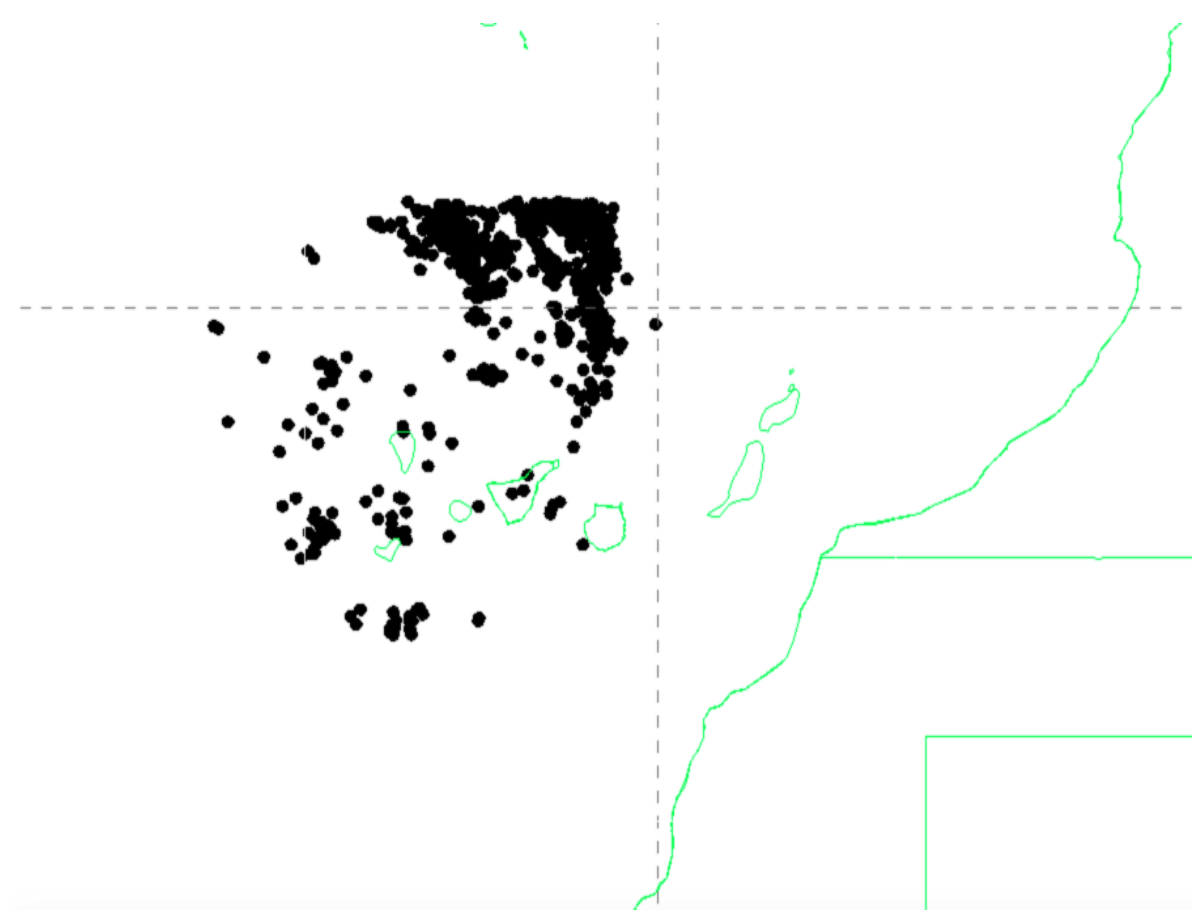

Figura 9: Descargas NT registradas por la red de detección de rayos de AEMET durante el día 22 de octubre. 


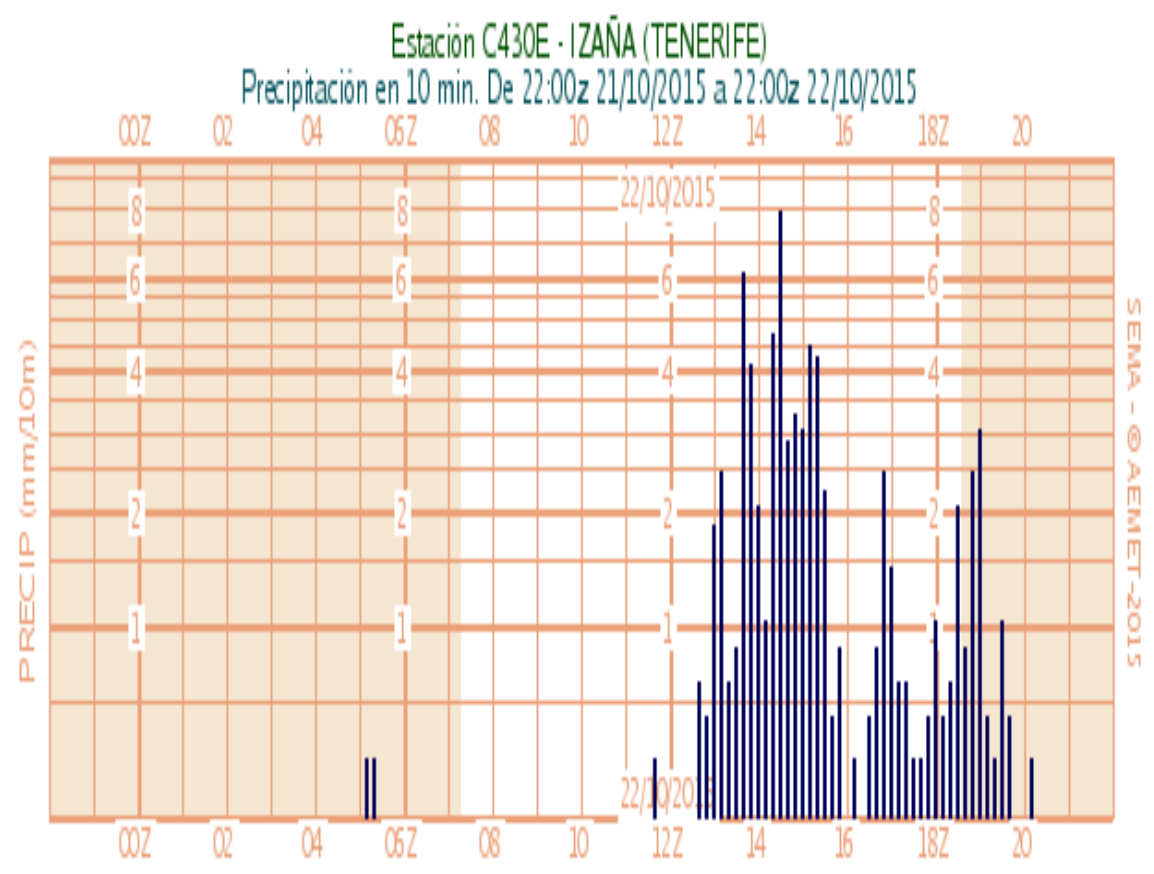

Figura 10: Precipitación registrada en la estación automática de Izaña (Tenerife) C430E de la red de AEMET durante el día 22 de octubre. 

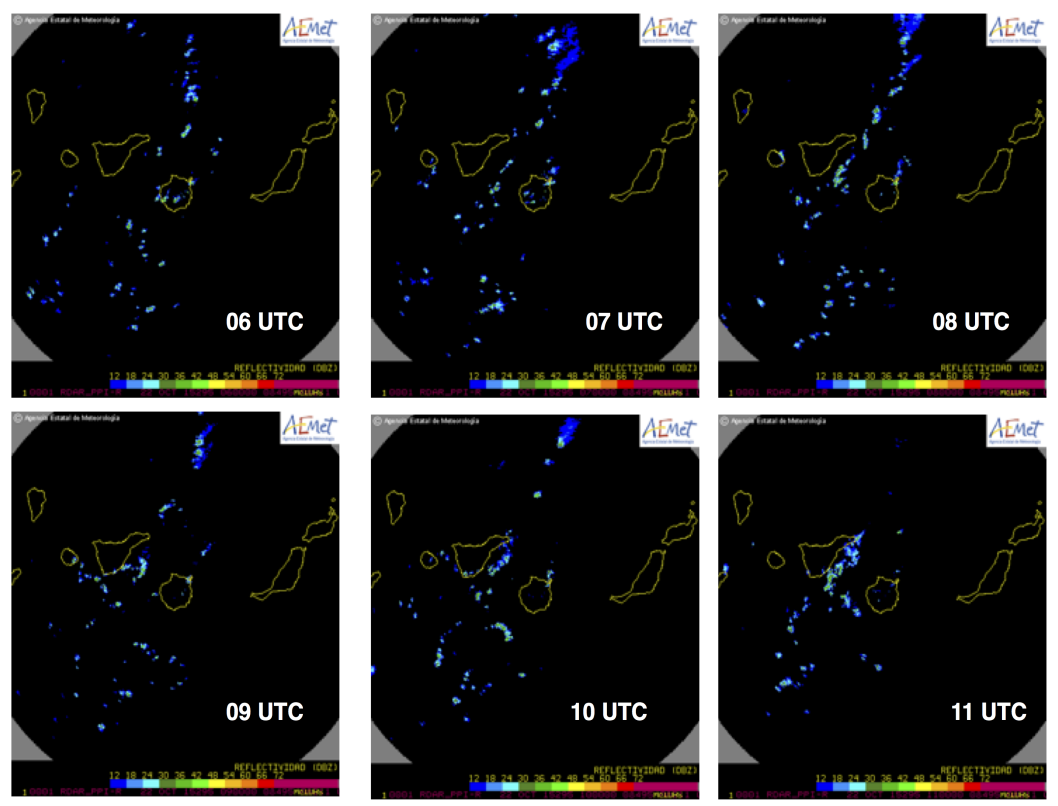

Figura 11: Secuencia de imágenes PPI del radar de AEMET ubicado en Gran Canaria durante el día 22 de octubre.

\subsubsection{Radar.}

El radar de Gran Canaria se ecuentra situado a 1781 metros de altura, en el Pico Morisco, al noroeste del Pico de las Nieves (punto más alto de la isla). La ubicación del radar es elevada ya que debe evitar la inversión de los alisios, además de salvar numerosos obstáculos geográficos. Es el radar más alto de la red de radares de España y este hecho introduce una limitación a la hora de inferir o estimar la intensidad de precipitación en superficie [Elizaga et al., 2003].

Estructura que afectó a Gran Canaria. En las secuencias de imágenes de PPI (figura 11) analizadas aparecen ecos de reflectividad moderada (35-40 dBZ) en la vertiente nordeste de Gran Canaria, afectando principalmente a los municipios de Las Palmas de Gran Canaria y Telde, desde las 06 a 10 UTC período en el cual se registraron las precipitaciones más intensas y los principales percances. Los ecos mencionados tienen la particularidad de no trasladarse hacia el norte o noroeste como lo hacen el resto de ecos de precipitación observados en el mar, sino que quedan cuasiestacionarios y desarrollando una estructura móvil con orientación suroeste-nordeste. Esta estructura quedaba dentro de una zona de convergencia a sotavento debida a la interacción del flujo del suroeste con la propia orografía de la isla, además de estar alimentada en niveles bajos por un flujo marítimo de intensidad débil, con un continuo aporte de humedad. Esto favoreció el anclamiento de los núcleos convectivos y la eficacia de las precipitaciones.

Estructura que afectó a Tenerife. En las imágenes de PPI entre las 10 y 20 UTC (figuras 11 y 12) se observan ecos de reflectividad moderada (35-40 dBZ) en una estructura lineal (presunta línea de turbonada) orientada de suroeste a nordeste que se desplazó de forma anómala en dirección noroeste y perpendicular al flujo medio o rector desde el canal Anaga-Agaete hacia Tenerife (el flujo medio o rector entre 0 a $6 \mathrm{~km}$ era del suroeste), [Bunkers et al., 2000], [Craven, 2000]. En el modelo conceptual básico, una línea de turbonada es una línea de convección que se propaga en sentido perpendicular al vector cizalladura del viento medio o flujo rector medio [COMET, 2016a], [COMET, 2016b].

Una de las características de una línea de turbonada es el chorro de entrada en la parte posterior 

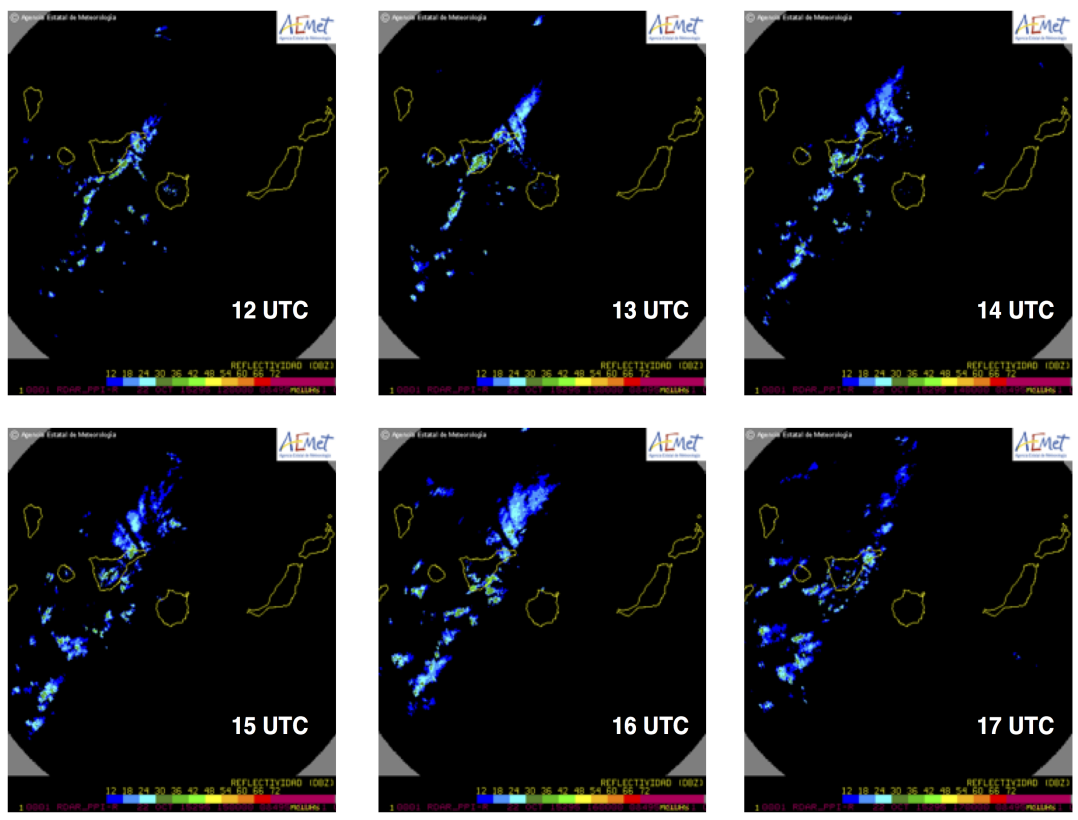

Figura 12: Secuencia de imágenes PPI del radar de AEMET ubicado en Gran Canaria durante el día 22 de octubre.

de la tormenta. Tales chorros ocurren en entornos de CAPE alto con intensa cizalladura vertical del viento. El chorro de entrada posterior acelera el flujo de la parte de atrás de la línea de turbonada y aumenta las potenciales ráfagas de viento en la superficie. En los datos de viento de la estación de Izaña (figura 13) se puede apreciar cómo a partir de las 14 UTC las rachas de viento aumentaron desde 25 a $70 \mathrm{Km} / \mathrm{h}$, coincidiendo con los picos de intensidad máxima de precipitación (figura 10).

Otra estructura que puede surgir en las líneas de turbonada, y que parece apreciarse en la imagen de las 13 UTC de la figura (figura 12), es una pareja de vórtices con giro ciclónico y anticiclónico. Dichos vórtices se forman cuando la corriente ascendente levanta la vorticidad en el borde de avance de la bolsa de aire frío y causa su inclinación. Una pareja de vórtices puede intensificar el chorro de entrada posterior y causar una curva, una protuberancia que se conoce como eco en forma de arco.

Cuando la estructura alcanzó Tenerife se produjo un realce en los ecos de reflectividad, alcanzándose máximos de 48 a $50 \mathrm{dBZ}$ en la zona central de la isla y en el extremo nordeste. Se aprecia que los principales focos se desplazaron hacia el nordeste o quedaron cuasiestacionarios, anclados en la orografía central del la isla y en el macizo de Anaga. La estructura se disipó en torno a las 20 UTC: eventualmente la bolsa de aire frío se adelanta a la convección que la engendra y la línea de turbonada se disipa. 


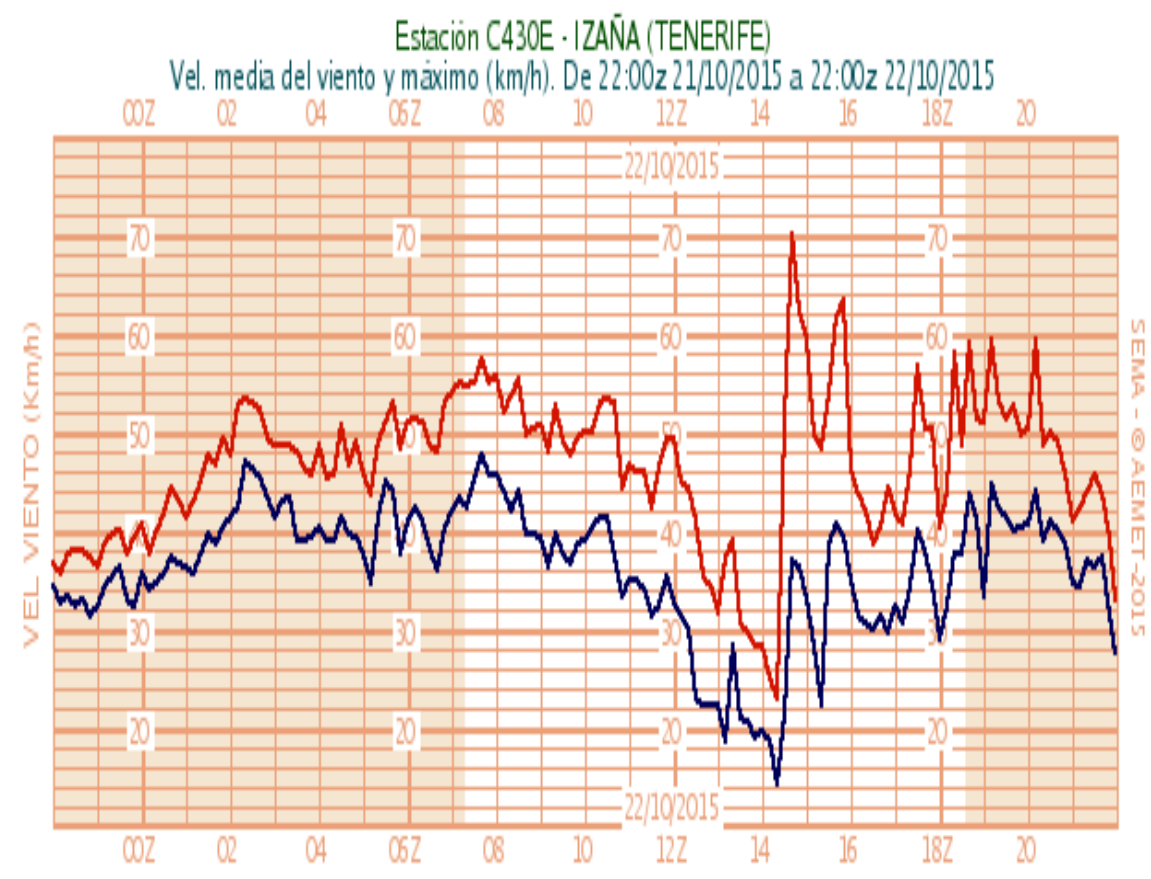

Figura 13: Viento registrado en la estación automática de Izaña (Tenerife) C430E de la red de AEMET durante el día 22 de octubre. 


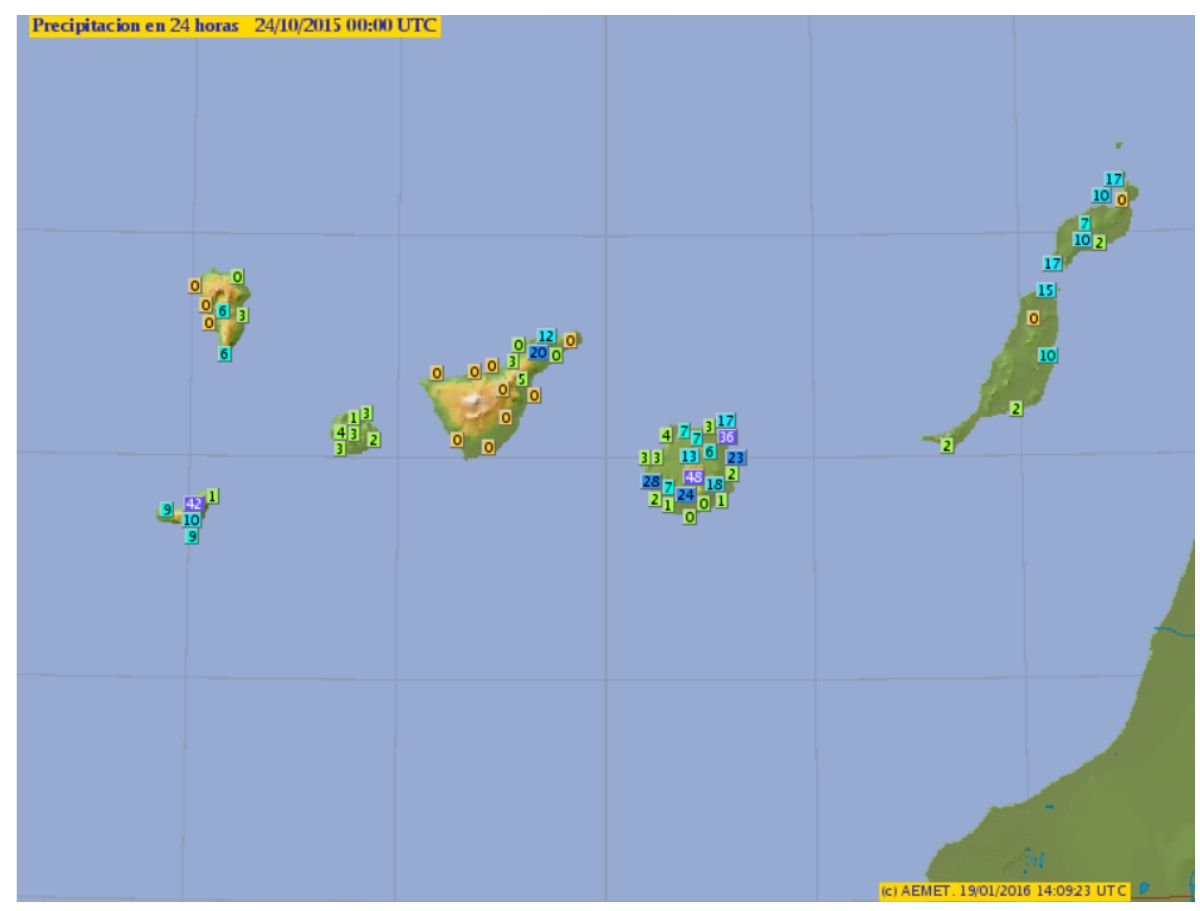

Figura 14: Estaciones AEMET del 23 a las 24 horas.

\subsection{El día 23 .}

El día en el que las lluvias alcanzaron su máximo fue el 23, en donde, durante la tarde, se obtuvo una precipitación superior a los 100 litros por metro cuadrado en torno al municipio de Telde, en la isla de Gran Canaria, tal y como informaron dos colaboradores (estaciones C648T y C649U de 129.4 y 107.5 litros de 7 del 23 a 7 del 24, respectivamente). En el resto de zonas los registros fueron significativamente menores en 24 horas (figura 14) aunque bastante significativos, evidenciando que se trató de un fenómeno de convección muy local, lo que siempre supone un reto para la predicción, máxime en Canarias.

Las predicciones y avisos de fenómenos meteorológicos adversos (FMA) realizados por el GPV de Canarias para este día mostraban la severidad de la situación, pronosticándose en todas las islas chubascos fuertes (entre 15 a $30 \mathrm{~mm} / \mathrm{h}$ ) y que podían ser localmente muy fuertes (30 a $60 \mathrm{~mm} / \mathrm{h}$ ), además estos boletines reflejaban que las precipitaciones irían acompañadas de tormentas.

Se adjunta la última actualización que se generó de la tabla de avisos previstos (figura 15) para el día 23 de octubre. Destacan los avisos naranja por precipitación en una hora (P1), es decir, precipitaciones muy fuertes de entre 30 a $60 \mathrm{~mm} / \mathrm{h}$ en prácticamente todas las zonas y afectando a todas las islas.

\subsubsection{Entorno sinóptico y mesoescalar.}

El análisis del día 23 a las 00 horas (figura 16) pone de manifiesto la presencia de una baja al oeste de las islas que introduce aire tropical en el archipiélago y de la cual partían dos líneas de inestabilidad que llevaban actividad tormentosa asociada. Probablemente aún más importante es lo que podemos ver en la imagen (figura 17) de niveles altos, en la que se aprecian dos claros y bastante potentes chorros que inyectan más aire tropical. Obsérvese cómo las zonas de salida izquierda de los chorros, las zonas de más probabilidad de tiempo severo, casi coinciden exactamente con los lugares donde se registró más precipitación.

En niveles medios-altos se puede ver la vaguada encima de la baja en superficie, indicando que esa baja se estaba rellenando, y de hecho así fue en las horas posteriores del día 23. Esta vaguada fue 

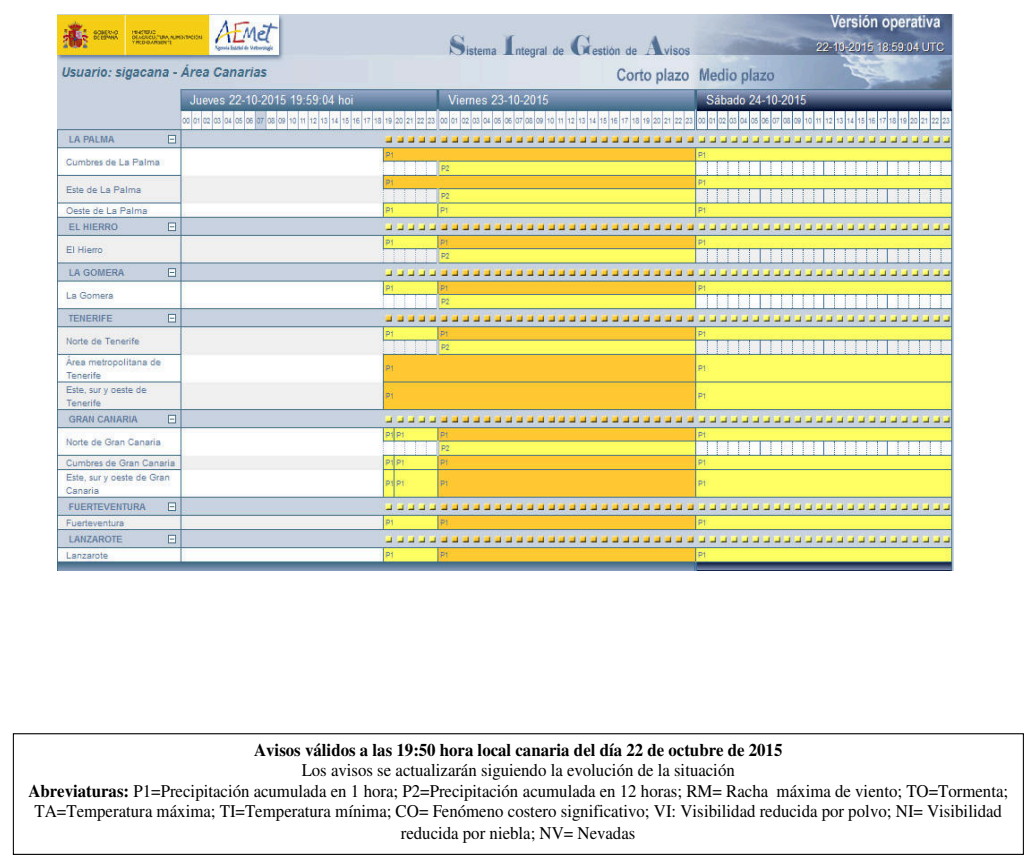

Figura 15: Avisos del día 23 de octubre de 2015 .

la DANA del día anterior. La vaguada tiene su zona de advección positiva de vorticidad y por tanto de mayor forzamiento dinámico también sobre la zona de interés (figura 18).

Es decir, que durante la tarde del día 23 de octubre de 2015, tuvo en la zona central y oriental de las islas Canarias una superposición de los siguientes tres factores:

- Zona de salida izquierda del chorro.

- Zona de inestabilidad y de convección (en general en todo el archipiélago).

- Zona de advección positiva de vorticidad situada corriente abajo de una vaguada.

Los tres son por separado indicadores de mayor potencial para el desarrollo de convección y en esta ocasión aparecieron simultáneamente. La zona tenía una gran potencialidad de tiempo severo. Estos indicadores, con la excepción de que en lugar de una vaguada era una DANA, estuvieron presentes también el día 22, y si bien la precipitación fue algo menor ese día, fue también muy apreciable. Podemos decir que a nivel sinóptico las situaciones fueron muy similares. Podría aventurarse que el 23 las precipitaciones fueron algo menores en las islas occidentales por la existencia de una vaguada (que no una DANA), pero nos parece algo temerario sacar esta conclusión. En El Hierro se ven más de 40 litros por metro cuadrado, por ejemplo. Es cierto que la vaguada parecía hacer un poco más de hincapié en la zona más oriental el día 23, pero teniendo en cuenta la compleja orografía, factor clave en concentrar flujos de humedad, así como los efectos más azarosos e impredecibles, pensamos que todo el archipiélago era susceptible de sufrir severidad convectiva, tanto un día como el otro.

\subsubsection{Análisis de sondeos.}

En las figuras (19 y 20) se muestran los radiosondeos de Güímar (Tenerife) relativos al día 23 a las 00 UTC y a las 12 UTC. Ambos perfiles muestran cómo la dirección del flujo rector continuaba siendo del suroeste y la intensidad aumentaba con la altura, presentando cizalladura unidireccional. La cizalladura de niveles bajos (SFC-1 km) y de niveles medios (SFC-3 km) en el sondeo de las 12 UTC fue en ambos casos de $3.08 \mathrm{~m} / \mathrm{s}$, en cambio la cizalladura entre $0-6 \mathrm{~km}$ fue de $12.86 \mathrm{~m} / \mathrm{s}$ (el 75 por ciento de los eventos severos ocurren con cizalladuras de una capa profunda 0-6 km de al menos $10 \mathrm{~m} / \mathrm{s}$ ). La SRH entre SFC-1 km fue de $20 \mathrm{~m}^{2} / \mathrm{s}^{2}$ y entre SFC-3 $\mathrm{km}$ de $32 \mathrm{~m}^{2} / \mathrm{s}^{2}$, algo inferiores a las obtenidas para el día anterior. 


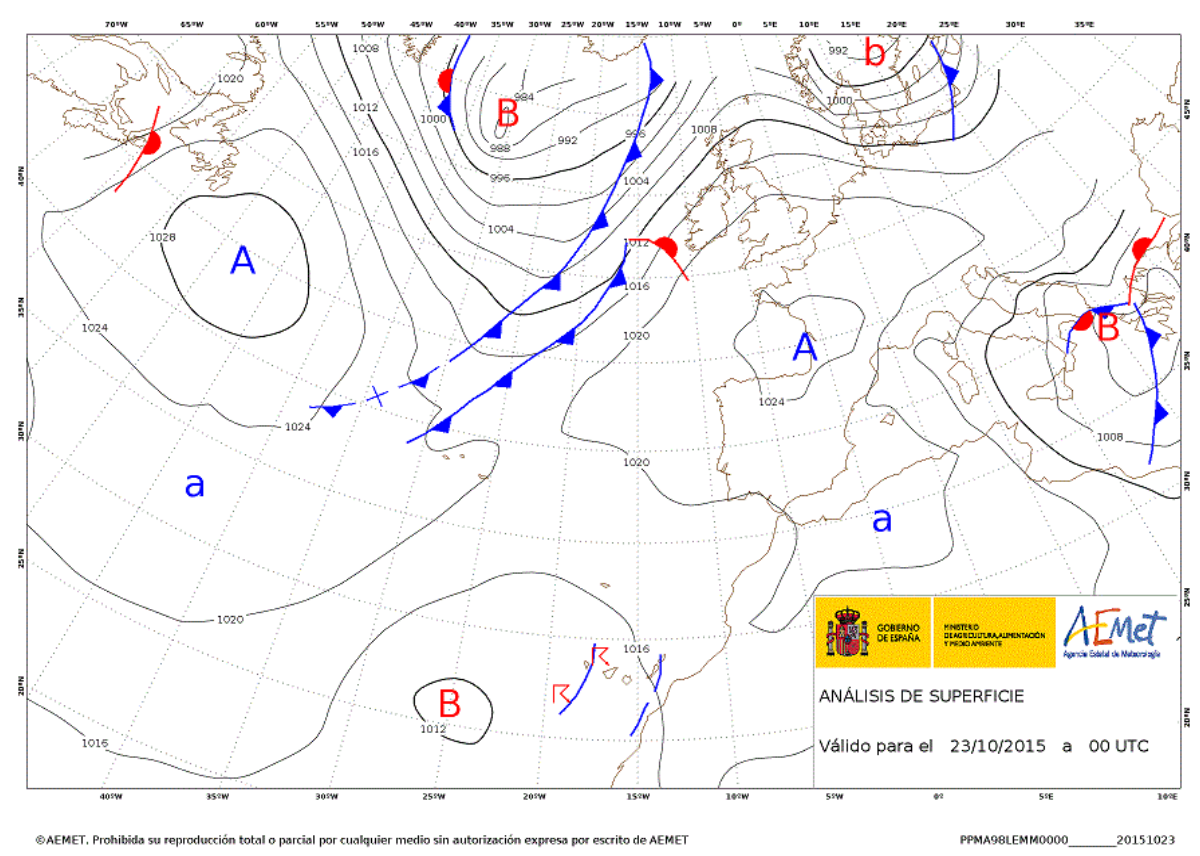

Figura 16: Superficie, día 23.

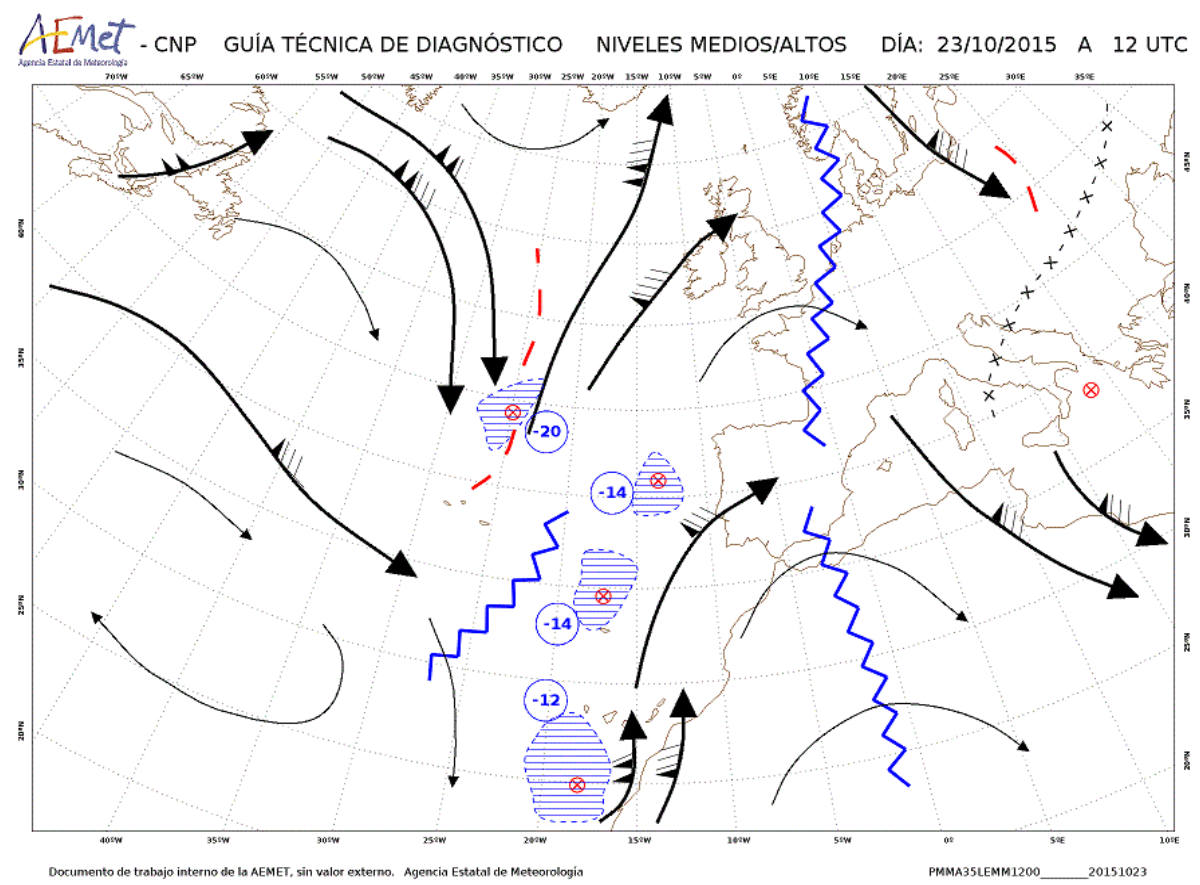

Figura 17: Niveles Altos a las 12 día 23. 


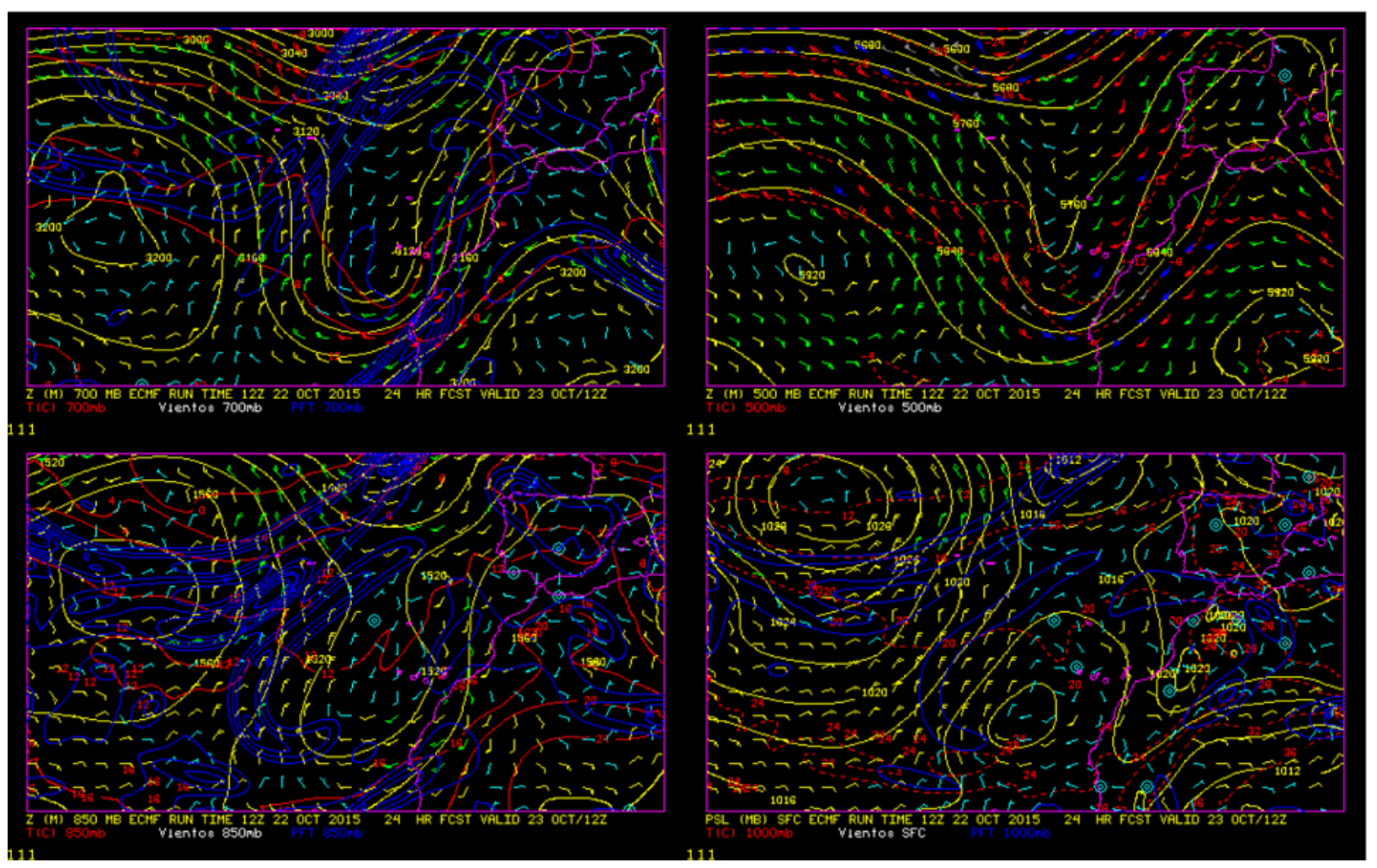

Figura 18: Pantalla sinóptica de McIdas día 23.

El sondeo de las 00 UTC (figura 19) muestra una inversión térmica de tierra (base a 105 metros) de $3^{\circ} \mathrm{C}$, inversión que desaparecería en el sondeo de las 12 UTC, favoreciendo las condiciones de potencial desarrollo de núcleos convectivos. El debilitamiento de la baja en superficie y el cambio de su posición respecto al día previo debilitó el aporte de humedad desde capas bajas hacia la zona donde se realiza el radiosondeo.

$\mathrm{El}$ gradiente vertical entre SFC-3 $\mathrm{km}$ fue de $7.5^{\circ} \mathrm{C} / \mathrm{km}$ y entre $700-500 \mathrm{hPa}$ de $6.4^{\circ} \mathrm{C} / \mathrm{km}$, estos valores están íntimamente relacionados (como comentamos en el análisis de sondeos del día previo) con situaciones de tormentas, tormentas severas o eventos de granizo.

Los índices clásicos de inestabilidad mostraron un entorno inestable, y los cambios más significativos los muestra la evolución del índice Lifted, que pasó de $1.15^{\circ} \mathrm{C}$ a $-2.03^{\circ} \mathrm{C}$, y la Energía Potencial Convectiva Disponible (CAPE), aumentando de 0 a $224.01 \mathrm{~J} / \mathrm{kg}$.

En el sondeo de las 12 UTC (figura 20) el NCA se situó a 899 metros el NCL a 1031 metros, esta escasa diferencia NCL-NCA parece síntoma de una probable convección profunda. Por otro lado, el NE se situó a 11.445 metros. El contenido en agua precipitable aumentó ligeramente desde 27.84 mm (00 UTC) a $30.75 \mathrm{~mm}$ (12 UTC).

\subsubsection{Rayos.}

En la figura (21) se presenta la actividad eléctrica nube-tierra (NT) registrada por los detectores de AEMET durante el día 23. Durante este día la actividad eléctrica fue significativamente menos intensa que el día precedente, registrándose 576 rayos en 24 horas, de los cuales 456 fueron rayos negativos y 120 rayos positivos. La inmensa mayoría de los rayos se produjeron en el mar, sin embargo es necesario hacer algunas consideraciones de los distintos focos convectivos.

La actividad tormentosa registrada al suroeste de la isla de El Hierro se produjo durante la 


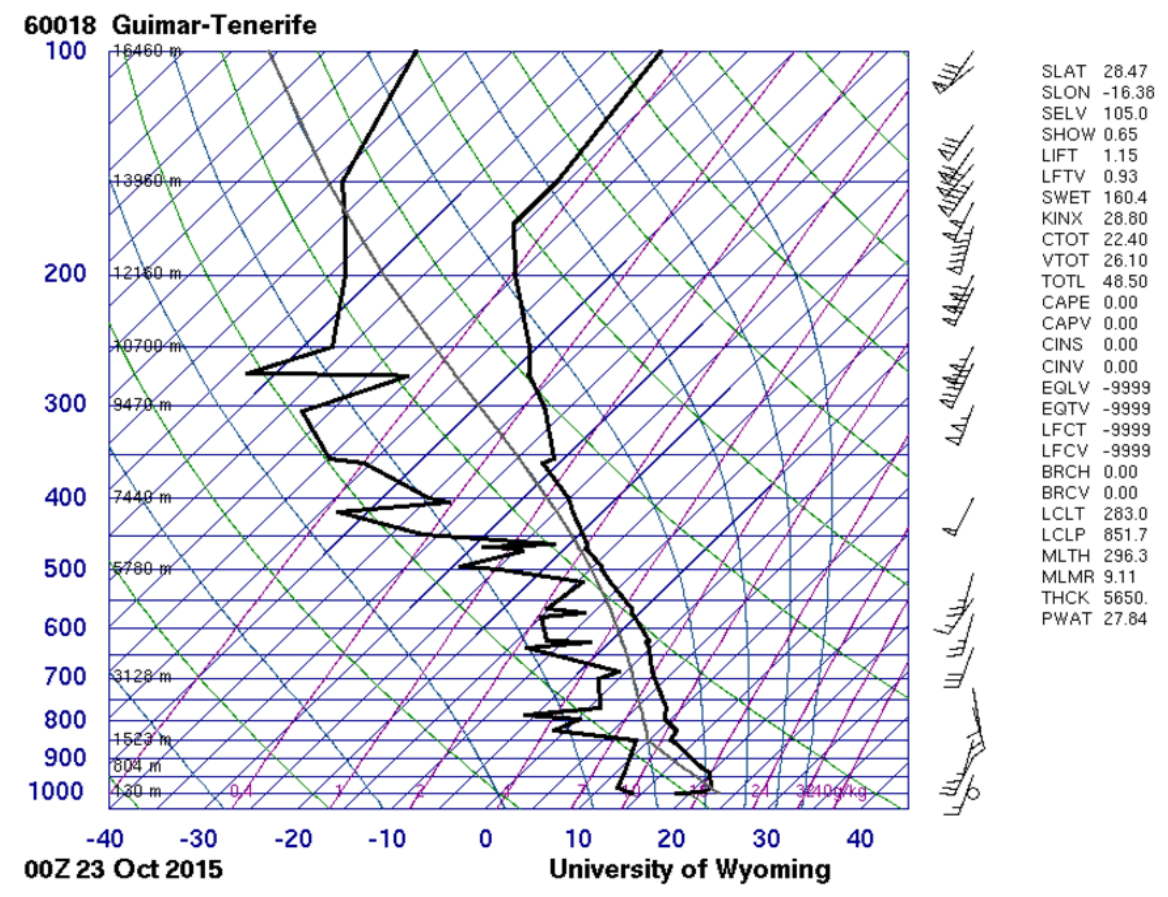

Figura 19: Radiosondeo del día 23 de octubre de 2015 las 00 UTC sobre Güímar (Tenerife).

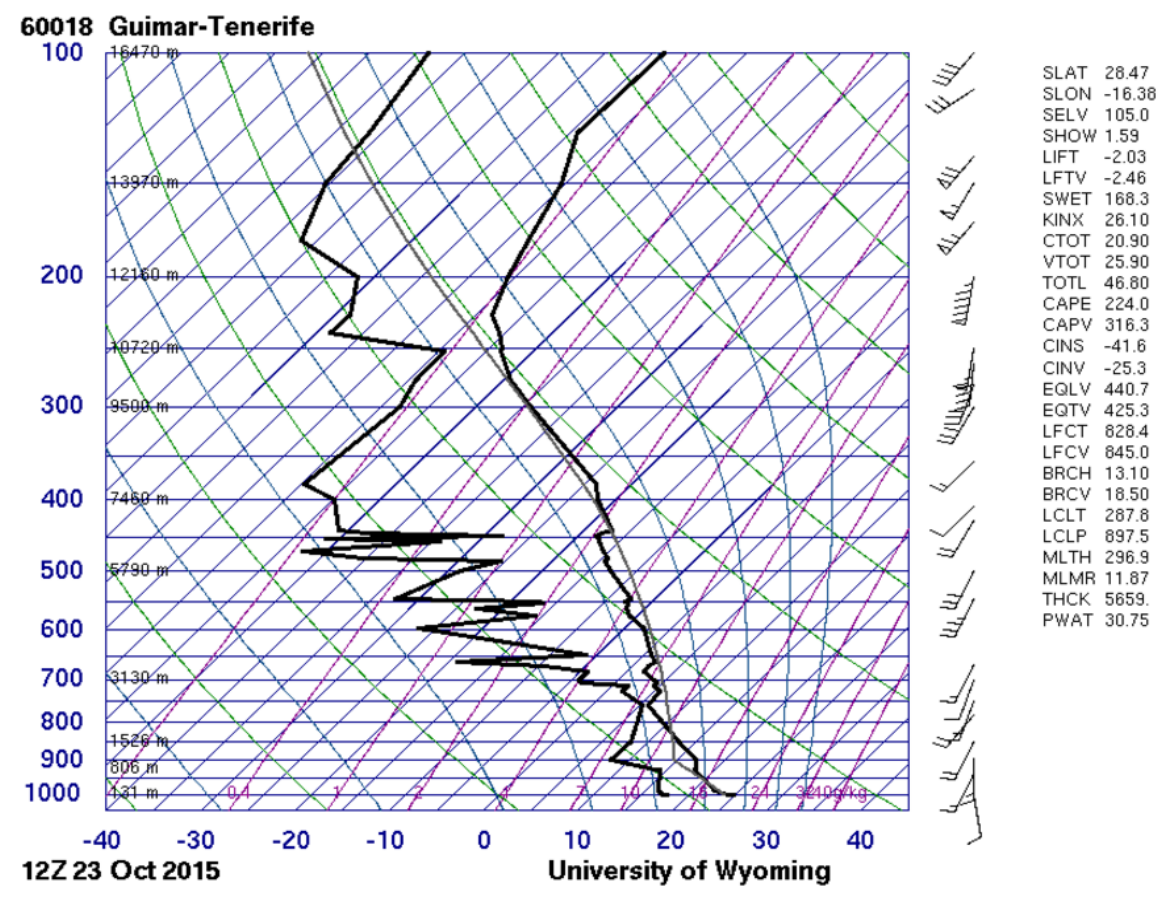

Figura 20: Radiosondeo del día 23 de octubre de 2015 de las 12 UTC sobre Güímar (Tenerife). 


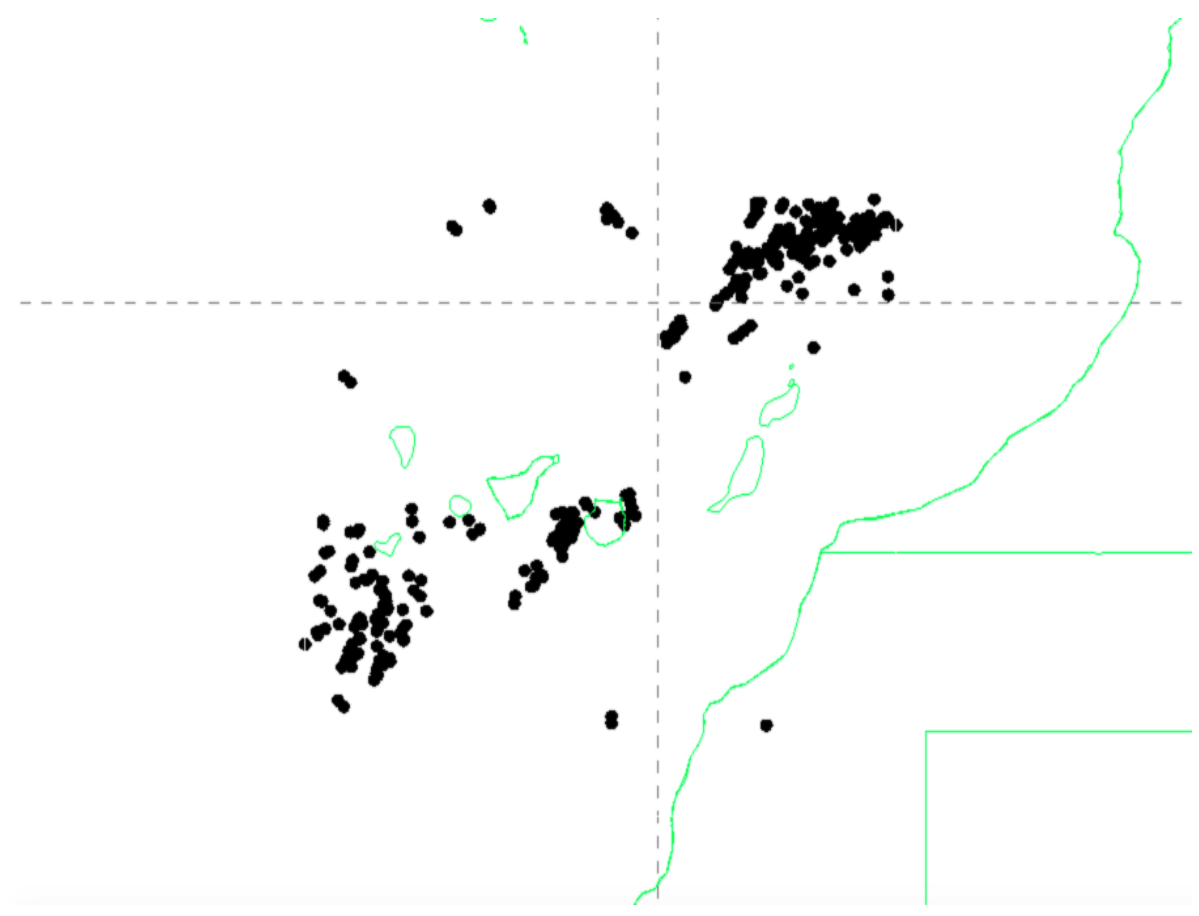

Figura 21: Descargas NT registradas por la red de detección de rayos de AEMET durante el día 23 de octubre.

madrugada y primeras horas de la mañana, donde hubo registros de precipitación de 42 litros en 24 horas (14), debido a los desarrollos producidos en el seno de la vaguada. Los desarrollos convectivos irían perdiendo organización con el paulatino desplazamiento y debilitamiento de la vaguada hacia el norte.

En el canal Anaga-Agaete, en las cercanías del litoral oeste de Gran Canaria, en los alrededores de los municipios de Telde y en Las Palmas de Gran Canaria la actividad eléctrica estuvo relacionada con una estructura mesoescalar que se generó en el citado canal Anaga-Agaete (figura 24) en torno a las 12-13 UTC, con orientación suroeste-nordeste originando a lo largo de la tarde las precipitaciones más intensas en la isla de Gran Canaria (figura 22).

En el mar, al norte de Lanzarote la actividad tormentosa estuvo directamente relacionada con la entrada de la masa húmeda e inestable desde el sur con origen subtropical. 
Estaciö C635B - SAN BARTOLOMETIRAJANA.HLLASTIRAJANAS (LAS PALMAS) Prexiptacion en 10 min. De 23:00z 222102015 a 23:02 23/102015

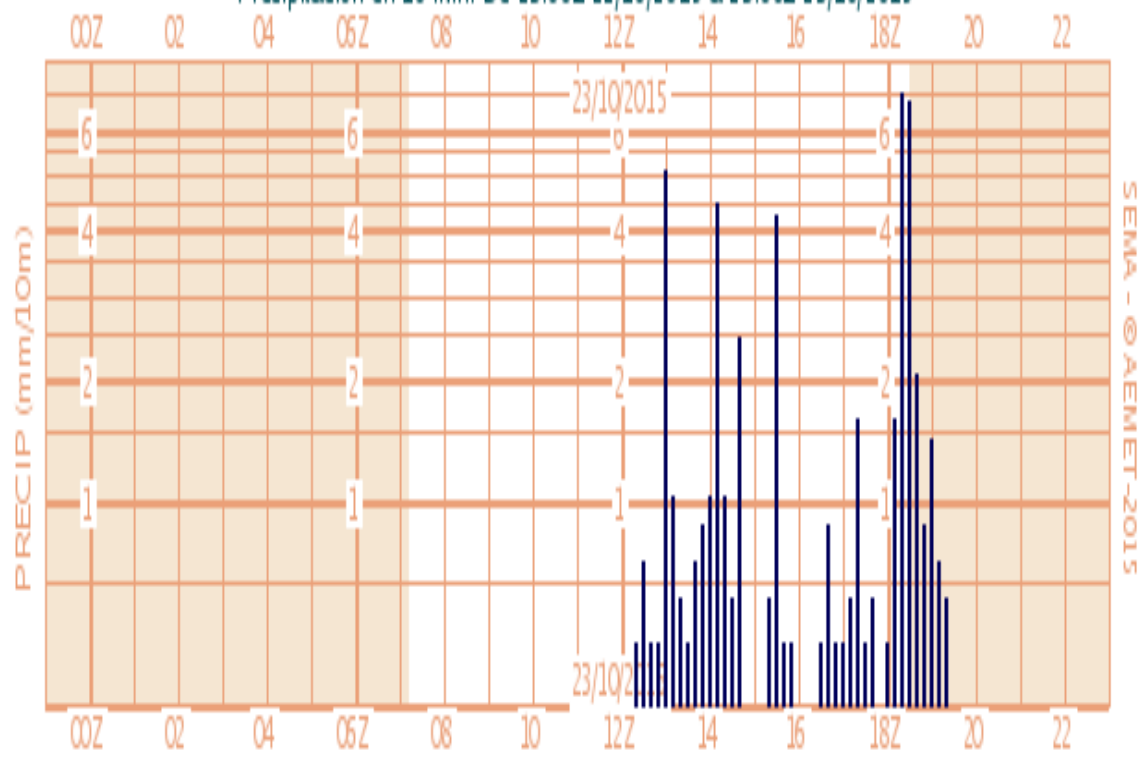

Figura 22: Precipitación registrada en la estación automática de San Bartolomes de Tirajana (Gran Canaria) C635B de la red de AEMET durante el día 23 de octubre. 

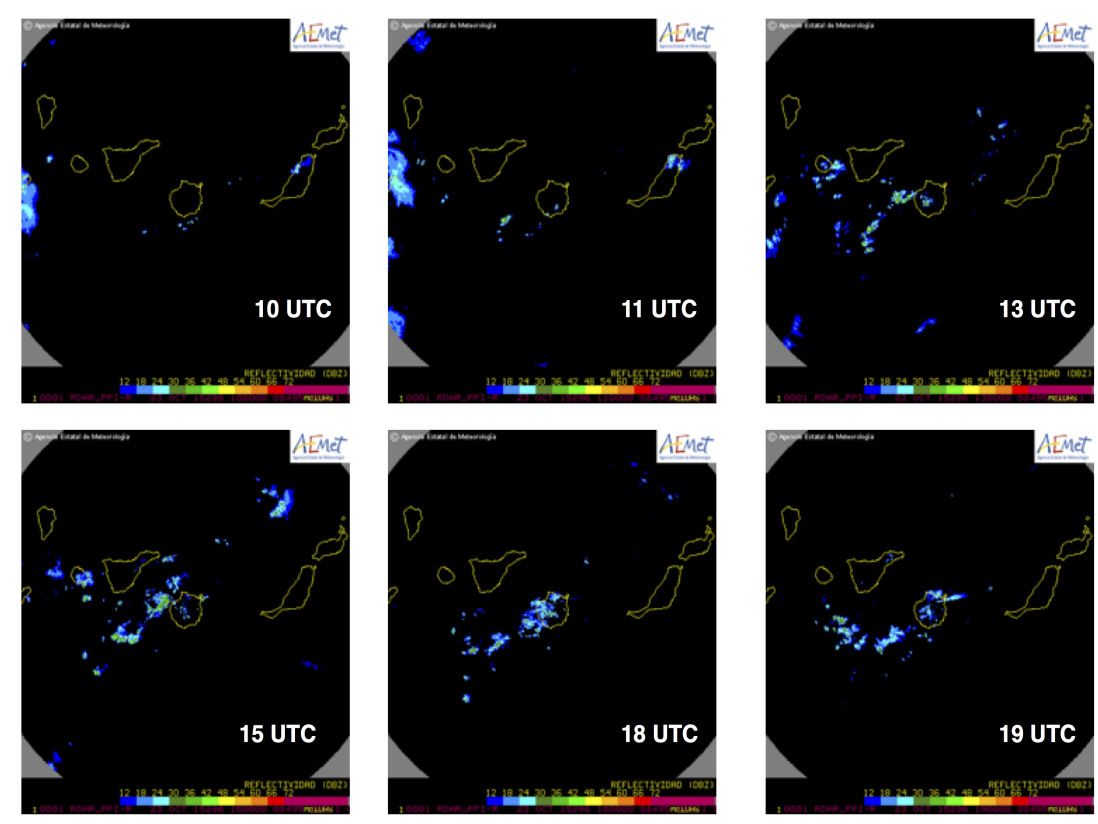

Figura 23: Secuencia de imágenes PPI del radar de AEMET ubicado en Gran Canaria durante el día 23 de octubre.

\subsubsection{Radar.}

El análisis de las imágenes PPI de radar de este día no revelan estructuras convectivas tan organizadas como las encontradas el día anterior. Sin embargo, cabe desglosar los datos en dos estructuras principales:

Estructura que afectó a El Hierro. La lejanía del radar a esta isla hace que la estimación de la precipitación mediante la reflectividad esté infravalorada. A pesar de esto se puede observar un foco convectivo con cierta organización entrando por el suroeste de la isla y desplazándose hacia el nordeste, entre las 09 y las 10 UTC (figura 23), con valores de 24 a 36 dBZ. Esta estructura sería la que a la postre provocaría las precipitaciones más abundantes en esta isla (figura 14).

Estructura que afectó a Gran Canaria. Los máximos de precipitación de este día se registraron en Gran Canaria. Los datos de radar revelan varios núcleos convectivos que se desplazan desde el suroeste hacia el nordeste en dirección al Canal de Anaga-Agaete, con valores de reflectividad entre 42 a 48 dBZ, a partir de las 12 UTC (figura 23). Una vez en el canal, las estructuras se desvían hacia el este-sureste, es decir, hacia Gran Canaria, originando las precipitaciones en esta isla y permaneciendo cuasiestacionarias hasta las 20 UTC. Quizás el mecanismo que desvió las estructuras de la trayectoria en el Canal (suroeste-nordeste) fue el apantallamiento orográfico de la propia isla de Gran Canaria al flujo de niveles bajos, permitiendo que la componente oeste de niveles medios-altos desplazase los focos convectivos hasta la isla, quedando, una vez allí, en estado cuasiestacionario (figura 24).

\section{Análisis de comportamiento de los modelos.}

Parece que la descripción de la sección anterior se pudiera deducir que la presencia de precipitaciones tan intensas como las que al final hubo era algo inmediato. No quisiéramos dar a entender que los análisis son tan sencillos ni tan directos. Una cosa es que a nivel sinóptico se cumplan los 


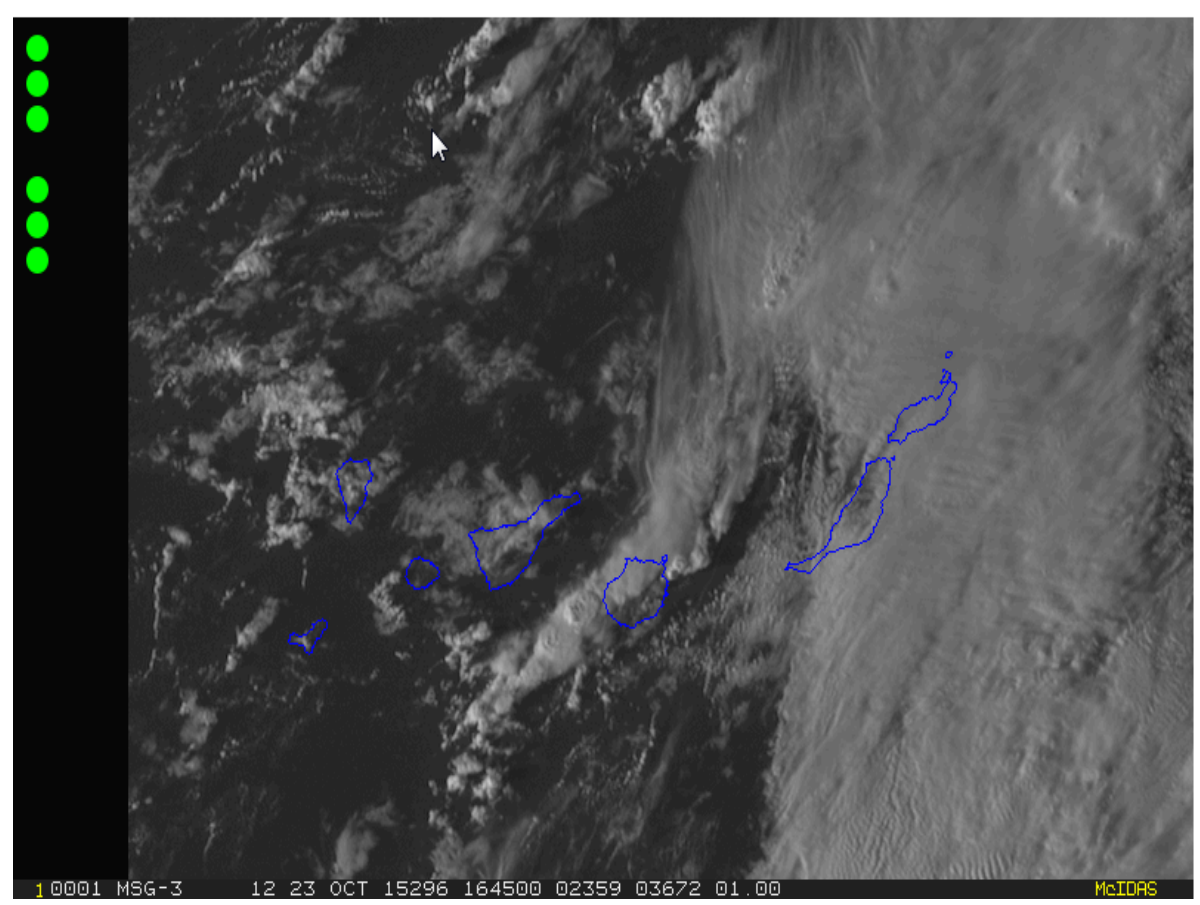

Figura 24: Imagen de alta resolución visible del día 23. Obsérvense los desarrollos convectivos al suroeste de Gran Canaria.

requisitos de tiempo severo, circunstancia que pone en aviso al predictor, y otra muy distinta afinar con las zonas donde van a tener lugar esas precipitaciones y en qué intervalo temporal, de modo que la predicción se traduzca en una herramienta útil para Protección Civil y el conjunto de los ciudadanos. Parece claro que para ello es fundamental el apoyo de los modelos numéricos de predicción. Veamos qué tal fueron.

\subsection{El día 22.}

\subsubsection{El modelo del Centro Europeo.}

El modelo del Centro Europeo es el principal modelo que los predictores del GPV de Las Palmas utilizan. Su resolución, aunque ha ido mejorando con el paso del tiempo notablemente, sigue siendo escasa para captar la orografía de las islas en toda su complejidad. Se han analizado las salidas disponibles para el día 22 de los distintos parámetros de interés para el estudio de la convección organizada. En las figuras (25) y (26), se observa que el modelo del Centro Europeo marcaba dos áreas donde habría que centrar la atención. Por un lado, sobre África, donde los valores de precipitación acumulada en 3 horas llegaban a $30 \mathrm{~mm}$. Esta zona estaba vinculada con la entrada de la masa húmeda subtropical y el modelo recogía pequeñas áreas de entornos ligeramente favorables para el desarrollo de la convección; por otro lado, alrededor de las islas occidentales el modelo preveía un entorno favorable para el desarrollo de la convección aunque las salidas de precipitación no eran elevadas (inferiores a $3 \mathrm{~mm}$ en 3 horas), excepto en el mar y al norte de Tenerife (10 $\mathrm{mm}$ en 3 horas). Es significativo observar cómo el modelo no pronosticó precipitaciones ni entornos convectivos en los alrededores de Gran Canaria.

El modelo pronosticó la situación con entornos de CAPE y SBCAPE entre de 200 a 1000 $\mathrm{J} / \mathrm{Kg}$ (principalmente en la mitad occidental), valores típicos observados en situaciones severas en el archipiélago canario, así como baja cizalladura (figura 27). Las salidas previstas del VIMD no muestran datos relevantes (figura ??).

Con los datos expuestos en esta sección es evidente que el modelo Centro Europeo no pronosticó 


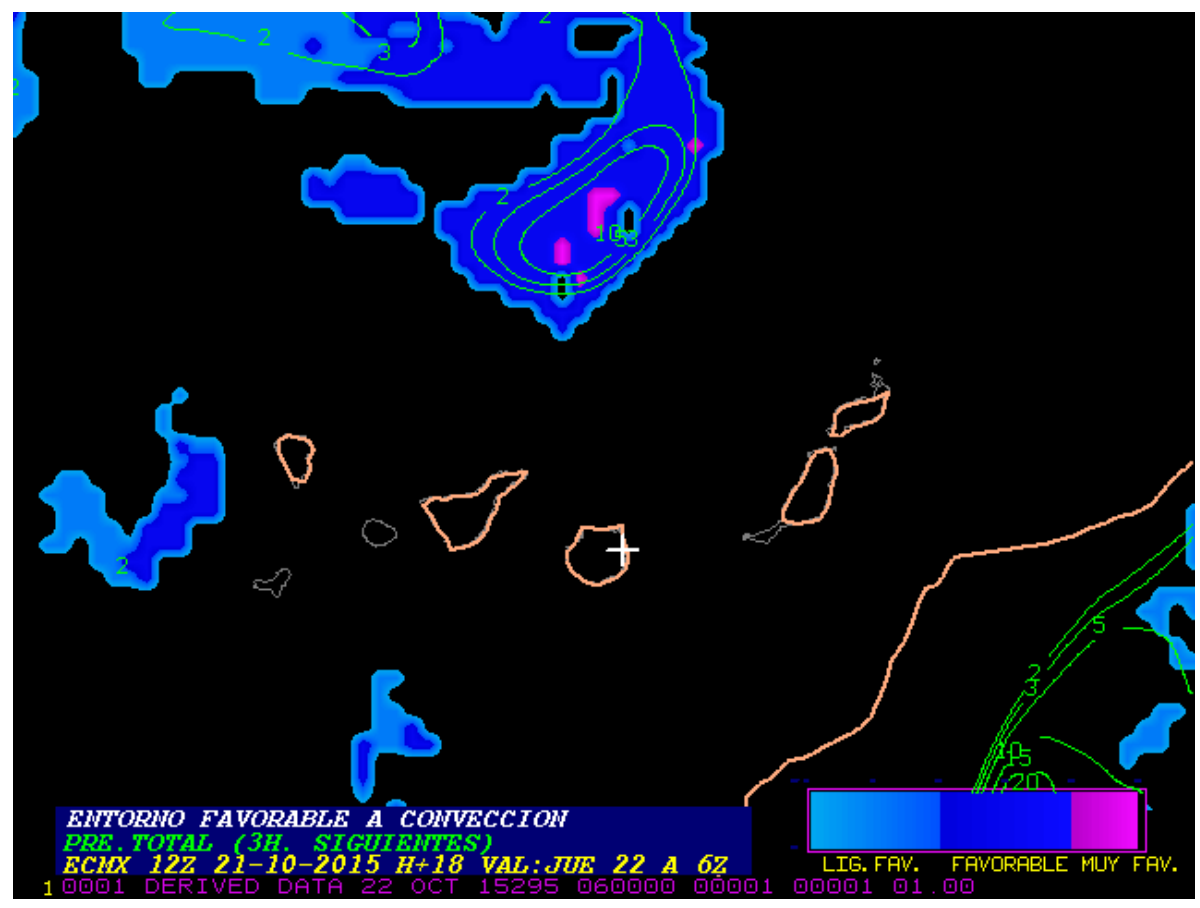

Figura 25: Entornos convectivos y precipitación en las 3 horas siguientes, día 22.

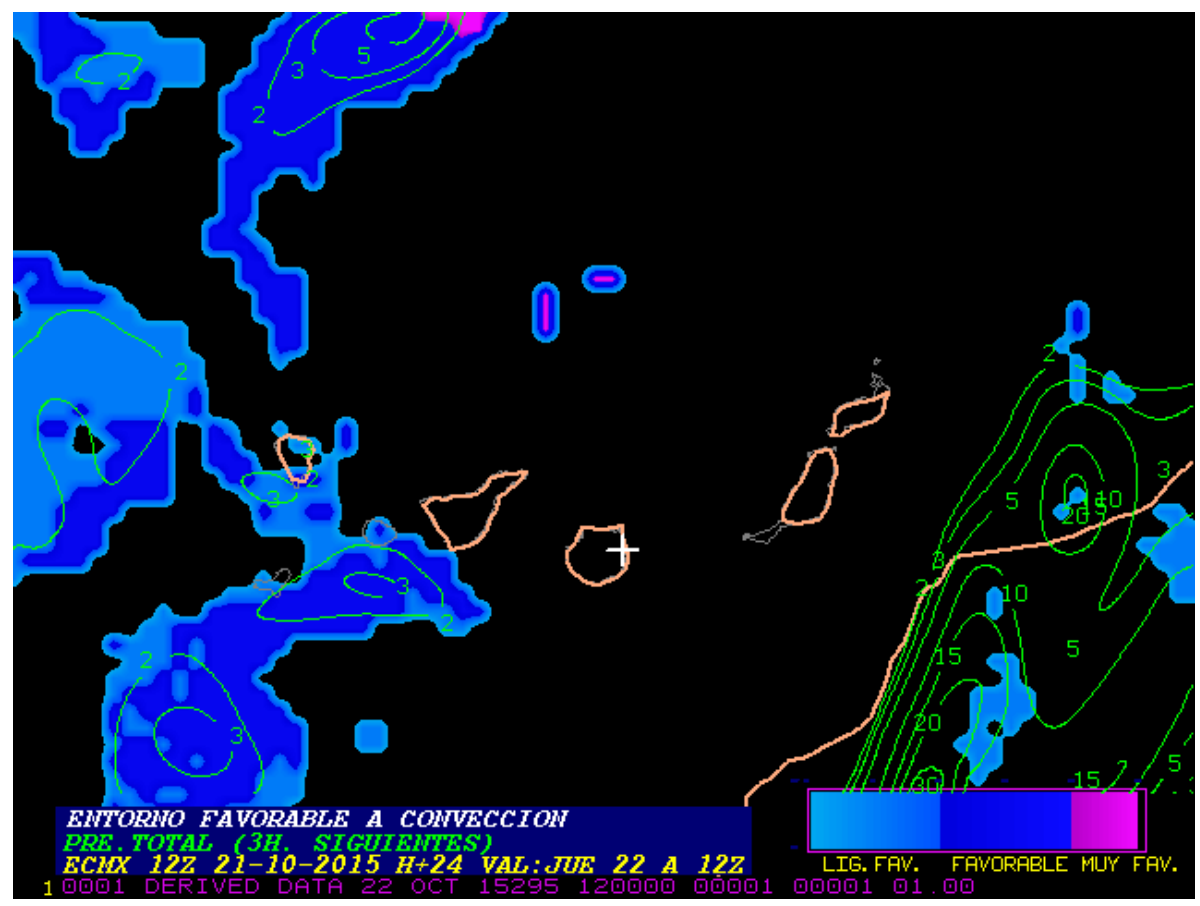

Figura 26: Entornos convectivos y precipitación en las 3 horas siguientes, día 22. 


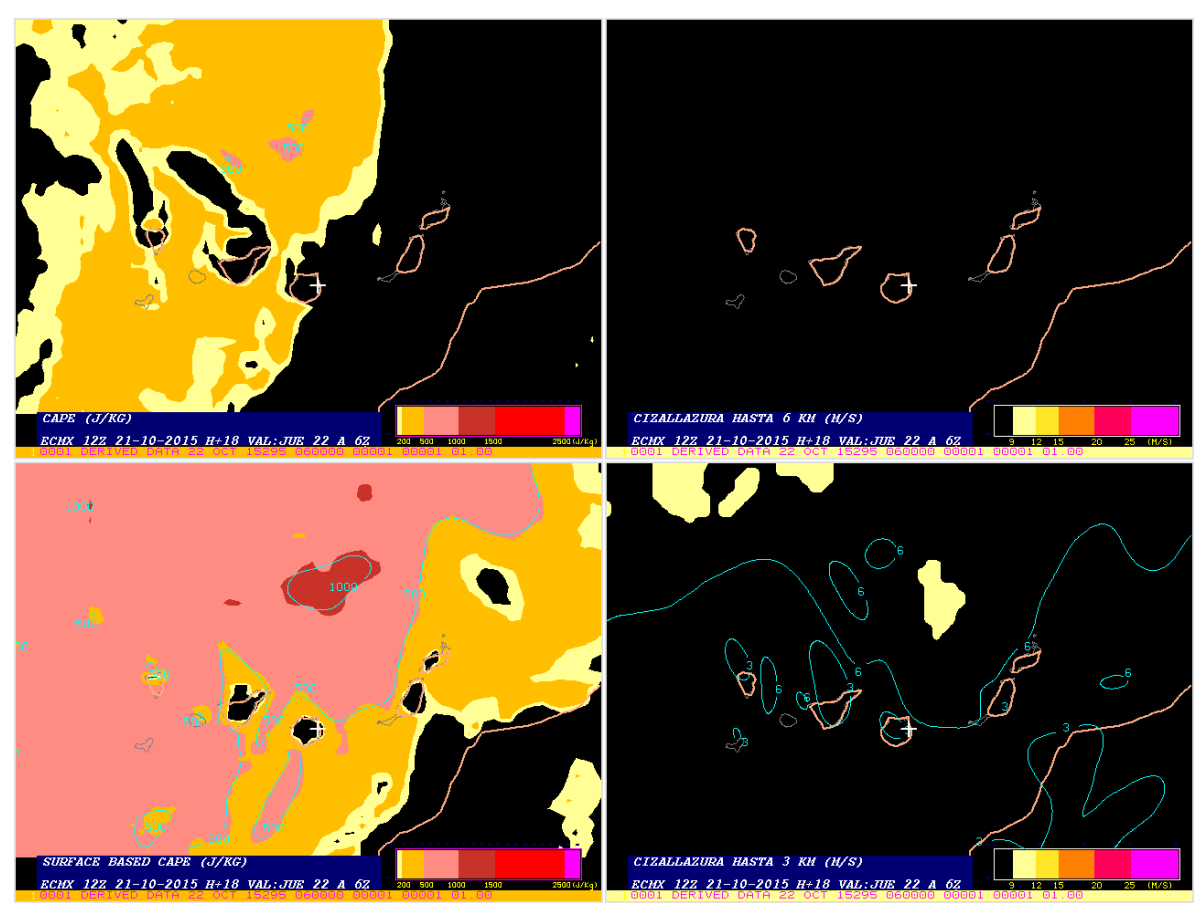

Figura 27: CAPE y cizalladura, día 22.

de forma correcta lo sucedido en Gran Canaria, dejándola en una zona de transición entre la DANA y la masa húmeda subtropical. Para el resto de islas captó lluvias pero subestimando mucho los valores. Pensamos que la interacción de los flujos con la compleja orografía de las islas acentúa la precipitación, probablemente a través de convergencias que en muchas ocasiones no son capaces de captar los modelos. 


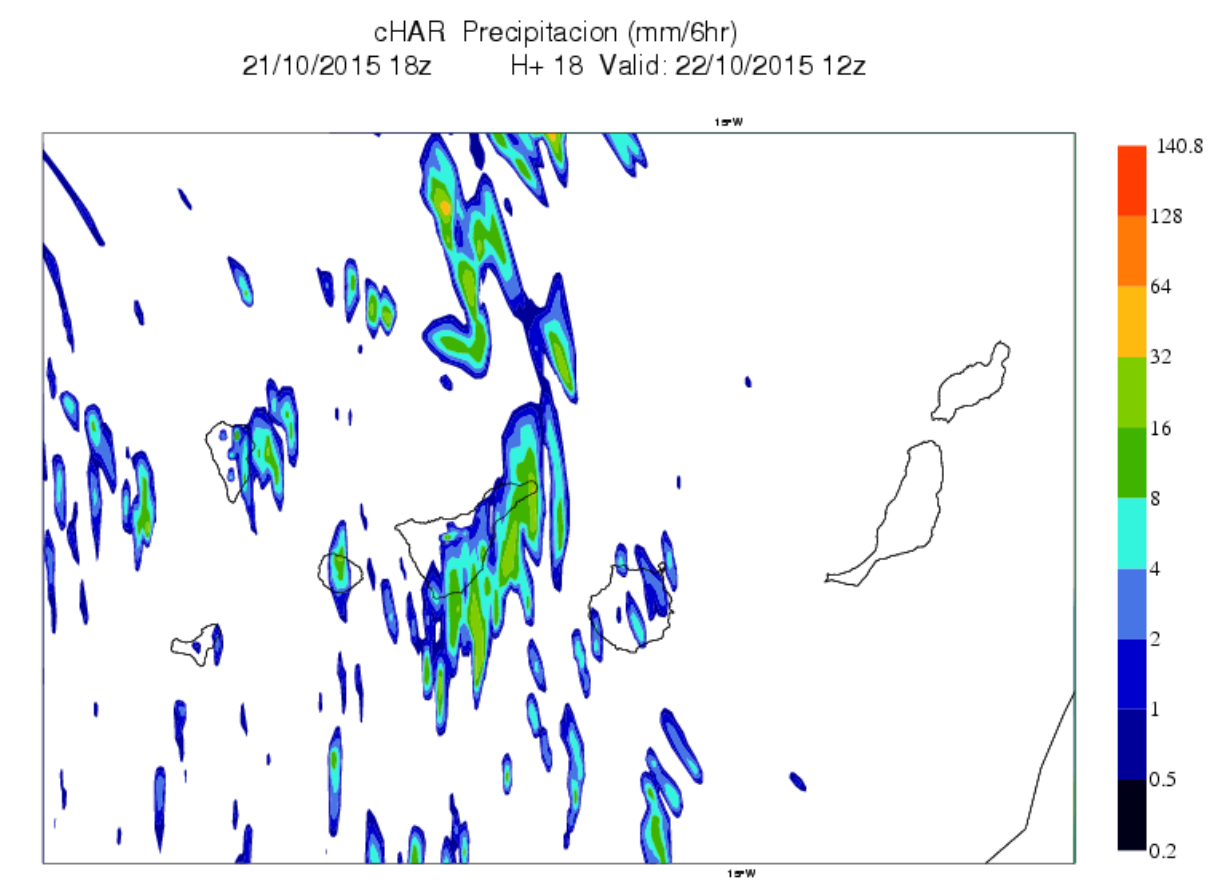

Figura 28: Precipitación acumulada en 6 horas del modelo Harmonie, pasada de las 18 del 21, de 06 a 12 horas.

\subsubsection{El modelo Harmonie.}

El modelo Harmonie ha empezado a utilizarse hace relativamente poco tiempo en Canarias. En el momento de escribir esto se va a iniciar una verificación local de su comportamiento con respecto a la predicción de la precipitación. La variable del viento en superficie, en cambio, está muy aceptada y de hecho se utiliza ampliamente para confeccionar los pronósticos de aeródromo. Sin embargo, con respecto a la lluvia, en varias ocasiones los predictores se han quejado de posible ruido o falsas señales, pero también es cierto que en otras ocasiones se ha alabado su precisión.

Para el día 22, el modelo apenas indicaba nada en las horas de la madrugada y empezaba a dar valores desde las 06 UTC (figura 28). Los máximos de la situación los ubicó en la zona de La Palma, (figura 29). Como comentaremos también para el análisis del día 23, estos máximos relativamente aislados del Harmonie son a veces sospechosos. En esta ocasión, sin embargo, y como podemos ver en los datos de las estaciones (figura 1), coincide que el máximo de la precipitación tuvo lugar en La Palma, con esos 100 litros al nordeste. No coincide la ubicación exacta, por supuesto, pero parece una buena aproximación. Las valores para el tramo final del día fueron significativamente menores y no se incluyen para no saturar de imágenes esta nota técnica. Sí parece claro también que los imporantes registros de más de 60 litros en el municipio de Telde no fueron captados en absoluto tampoco por el modelo Harmonie, al igual que sucedió con el modelo del Centro Europeo.

\subsection{El día 23.}

\subsubsection{El modelo del Centro Europeo.}

En las figuras (30 y 31) vemos que la salida directa de la precipitación más intensa se ubicó casi toda en el mar, y por supuesto las cantidades se subestimaron (aunque esto quizá es menos importante pues es conocido que el Centro Europeo tiende a infravalorar las precipitaciones). Un producto en fase experimental, como es el de entornos convectivos del CMT de Málaga, captó bien la zona de máxima inestabilidad. Podemos decir que el modelo intuyó la importancia de la zona (vaguada, inestabilidad, 


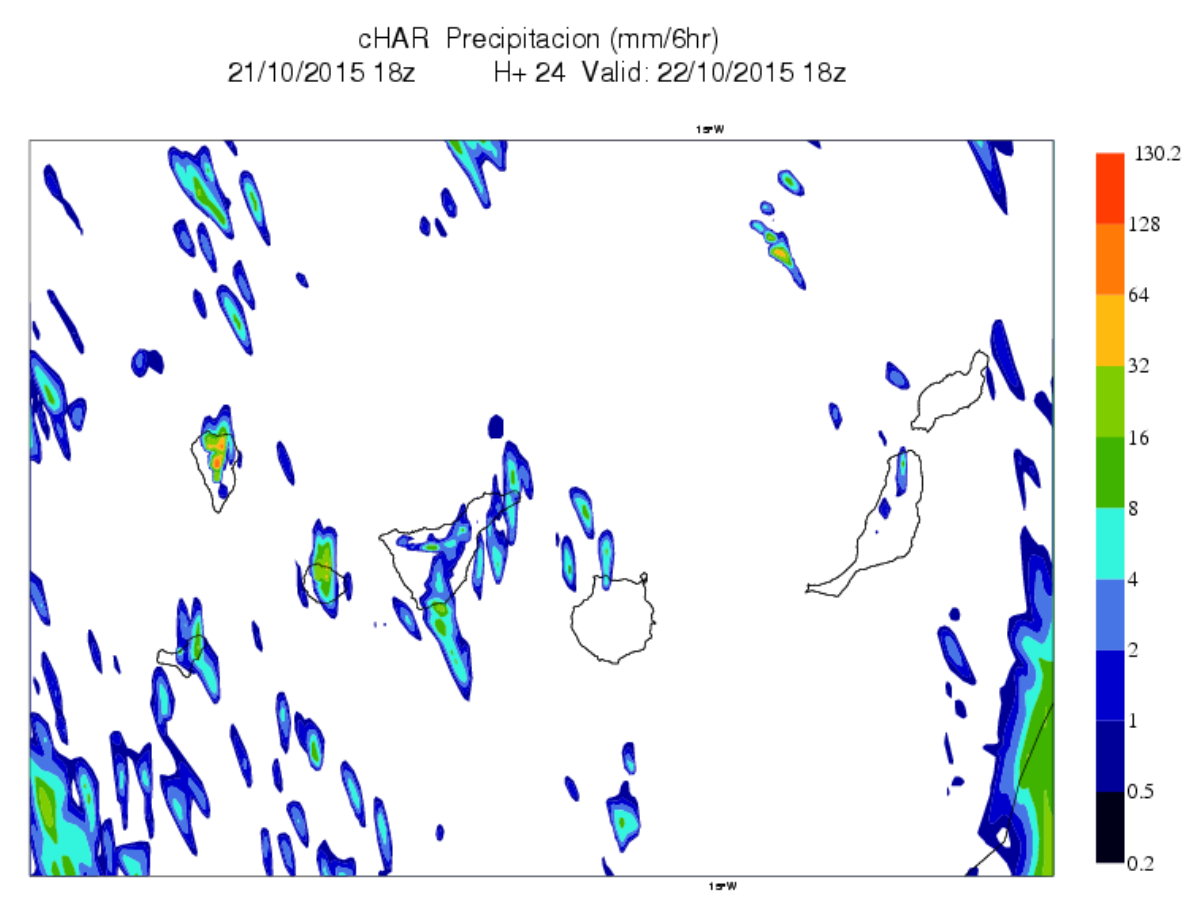

Figura 29: Precipitación acumulada en 6 horas del modelo Harmonie, pasada de las 18 del 21, de 12 a 18 horas.

chorro), pero no pudo ubicar el fenómeno adecuadamente. Bien es cierto que las ubicaciones a veces cambian con cada pasada del modelo.

Adjuntamos también otros campos derivados del modelo, por el interés que pudieran despertar. Especialmente destacable nos parece la ausencia total de señal del VIMD (divergencia de humedad integrada en la vertical), algo más de señal se obtiene de los campos qV, es decir, los campos usados para la VIMD pero no integrados en la vertical. De hecho, y como se pudo ver en algunas imágenes de satélite, hubo núcleos convectivos muy importantes justo antes de tocar la isla. Nótese también cómo el campo de convergencias en superficie no parece dar valores muy significativos. No pensamos que las convergencias no jugaran un papel relevante, de hecho creemos que es un factor a tener muy en cuenta, lo que sí consideramos es que muchas veces el modelo del Centro Europeo no es capaz de resolverlas o da algunas que son falsas, realzando la precipitación de forma irreal. Probablemente, aunque en menor medida, al Harmonie le pasa lo mismo; sin duda, hacen falta más estudios sobre este tema.

El grueso de la dinámica de la situación venía a través de niveles medios y altos y el modelo del Centro Europeo ve las islas con una altura muy inferior a la real. Por supuesto, podría haber factores muy locales, como hemos comentado, que el modelo fue incapaz de resolver y que explicarían por qué los más de cien litros cayeron justo en Telde y no en otros municipios adyacentes. Sin embargo, hay que tener en cuenta que las imágenes de satélite mostraban importantes desarrollos en el mar fuera de toda orografía. Nosotros creemos que el relieve no jugó un papel tan importante en esta ocasión, que la inestabilidad era fundamentalmente sinóptica y que en esa región toda zona era susceptible de desarrollar convección severa, estando la explicación de por qué en un lugar y no en el adyacente probablemente en fenómenos caóticos de muy pequeña escala.

\subsection{2. $\quad$ El modelo Harmonie.}

El Harmonie identificó una zona de importante precipitación en la tarde del día 23 alrededor y sobre Gran Canaria (figura 36) para la pasada de las 00 del 23. Esta señal la ubicó muy bien sobre lo que sería el municipio de Telde en la última pasada válida, la de las 06 (figura 37) (la pasada de 


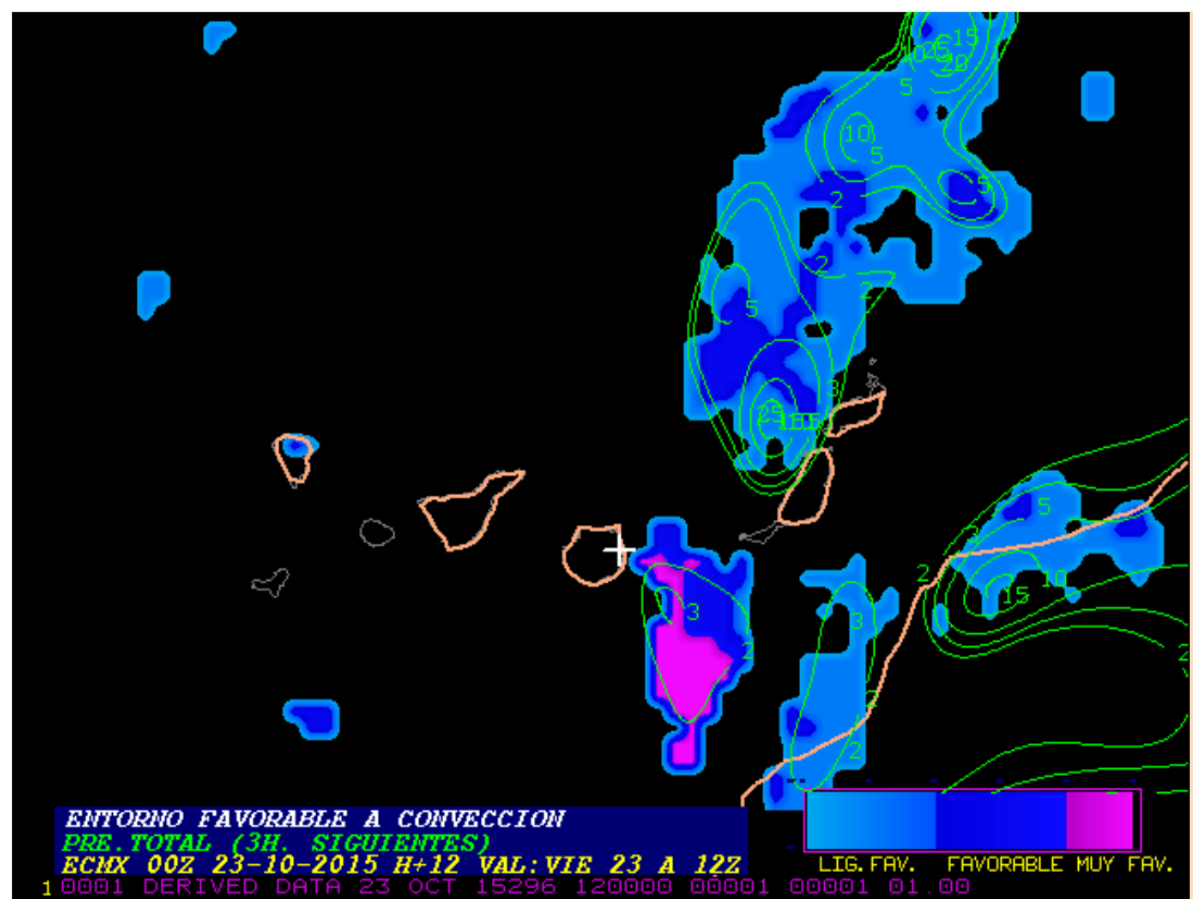

Figura 30: Entornos convectivos y precipitación en las 3 horas siguientes, día 23.

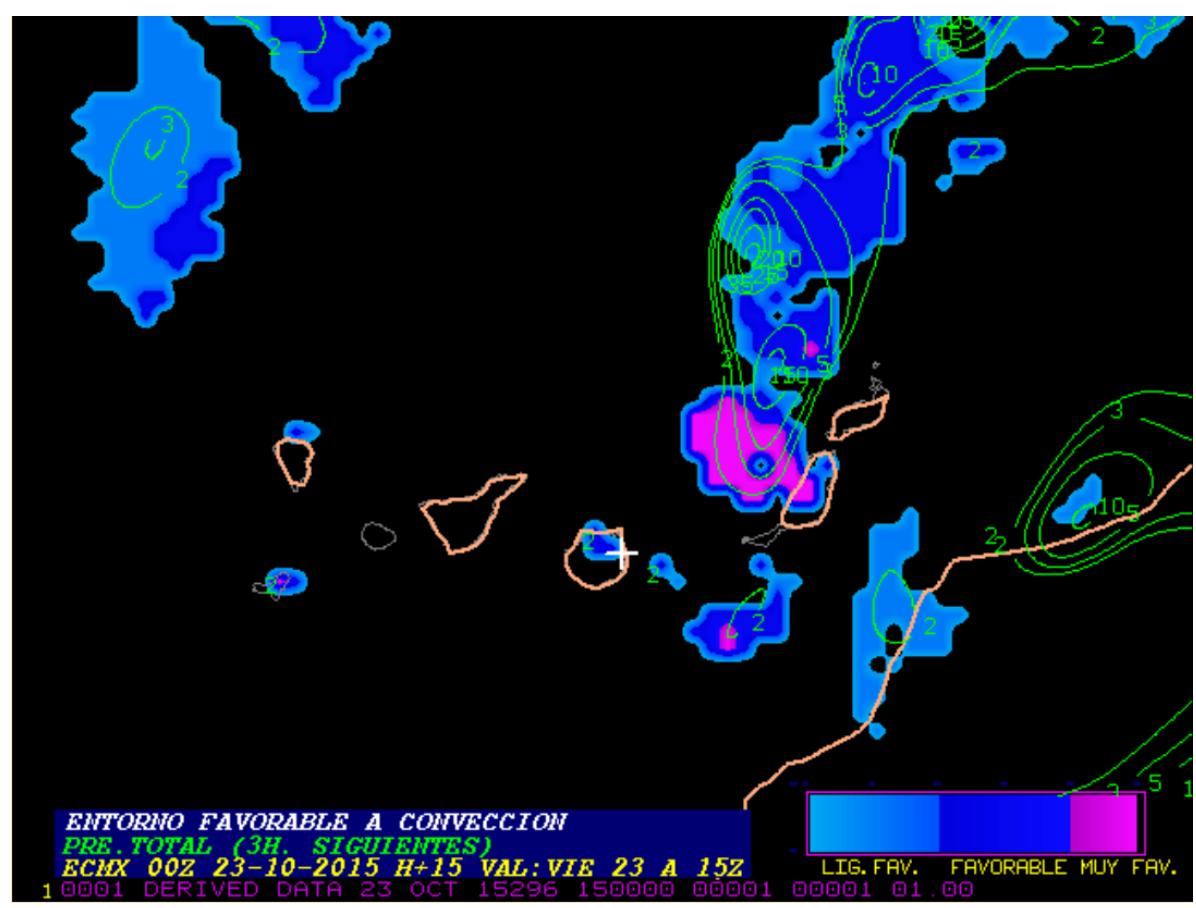

Figura 31: Entornos convectivos y precipitación en las 3 horas siguientes, día 23. 


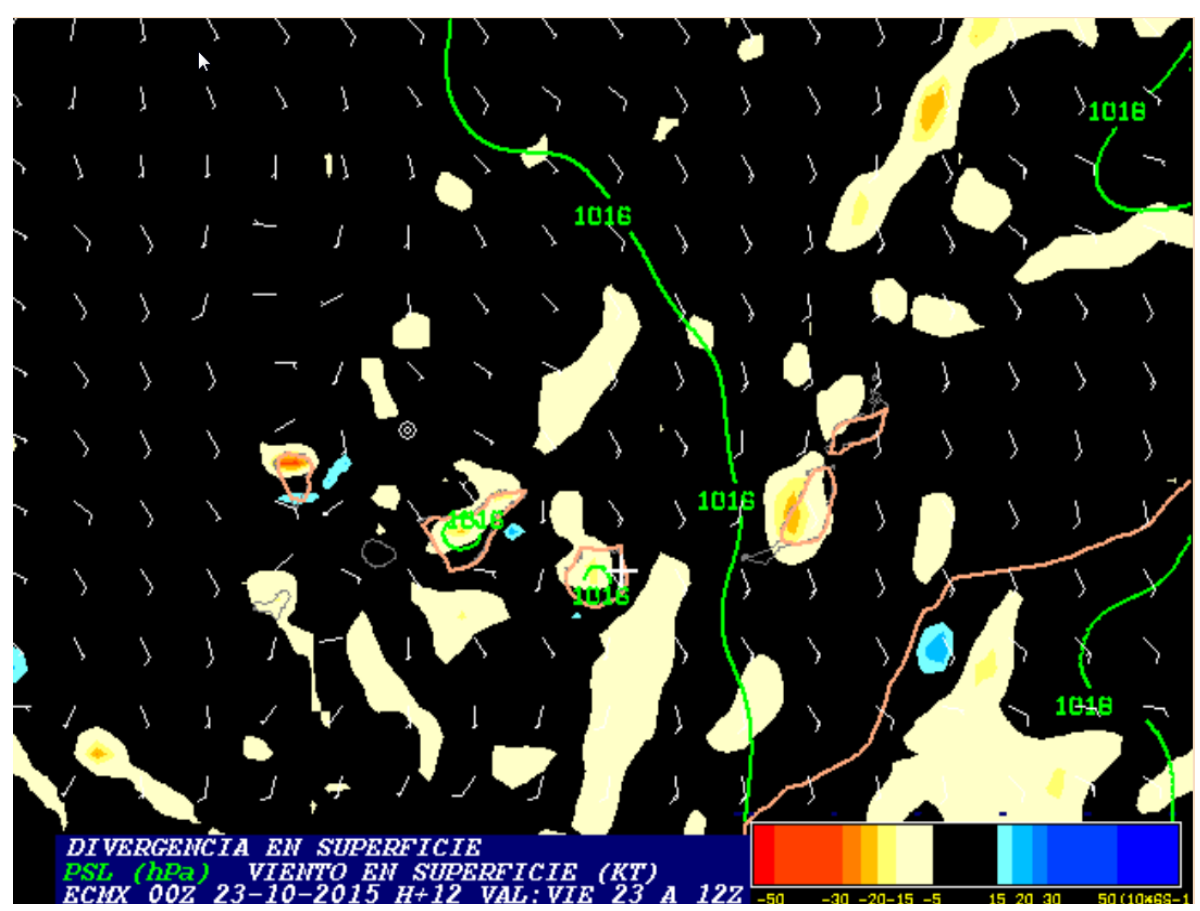

Figura 32: Campo de viento en superficie y convergencias/divergencias a las 12, día 23.

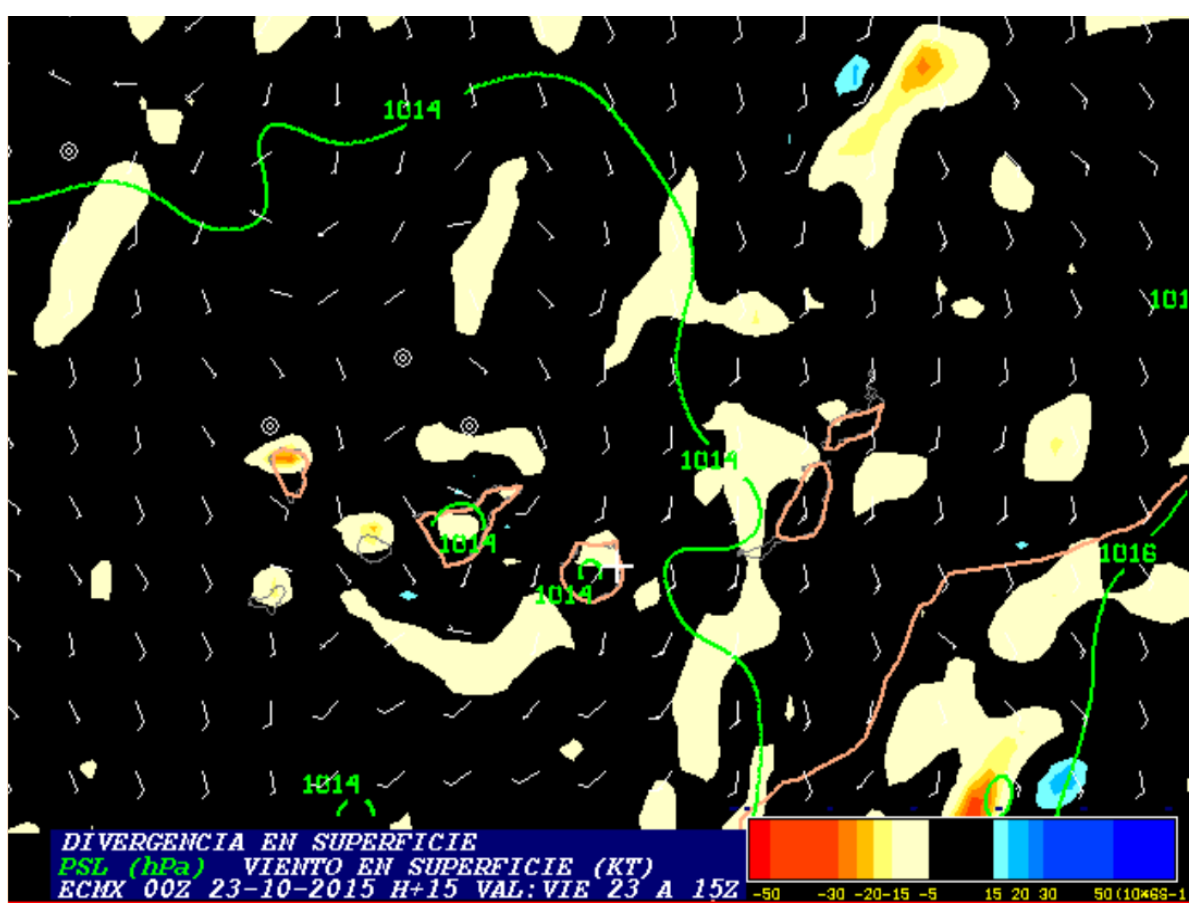

Figura 33: Campo de viento en superficie y convergencias/divergencias a las 15, día 23. 


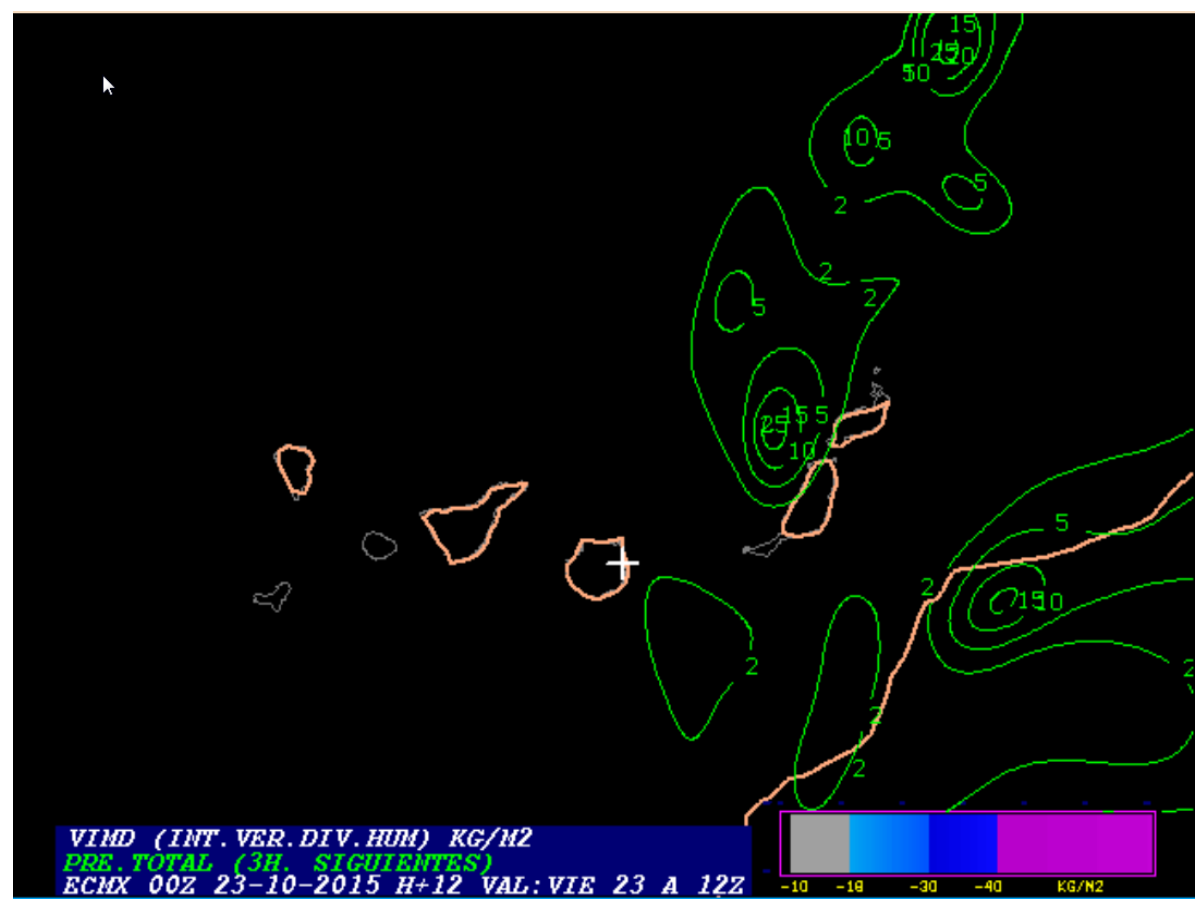

Figura 34: VIMD a las 12 del día 23.

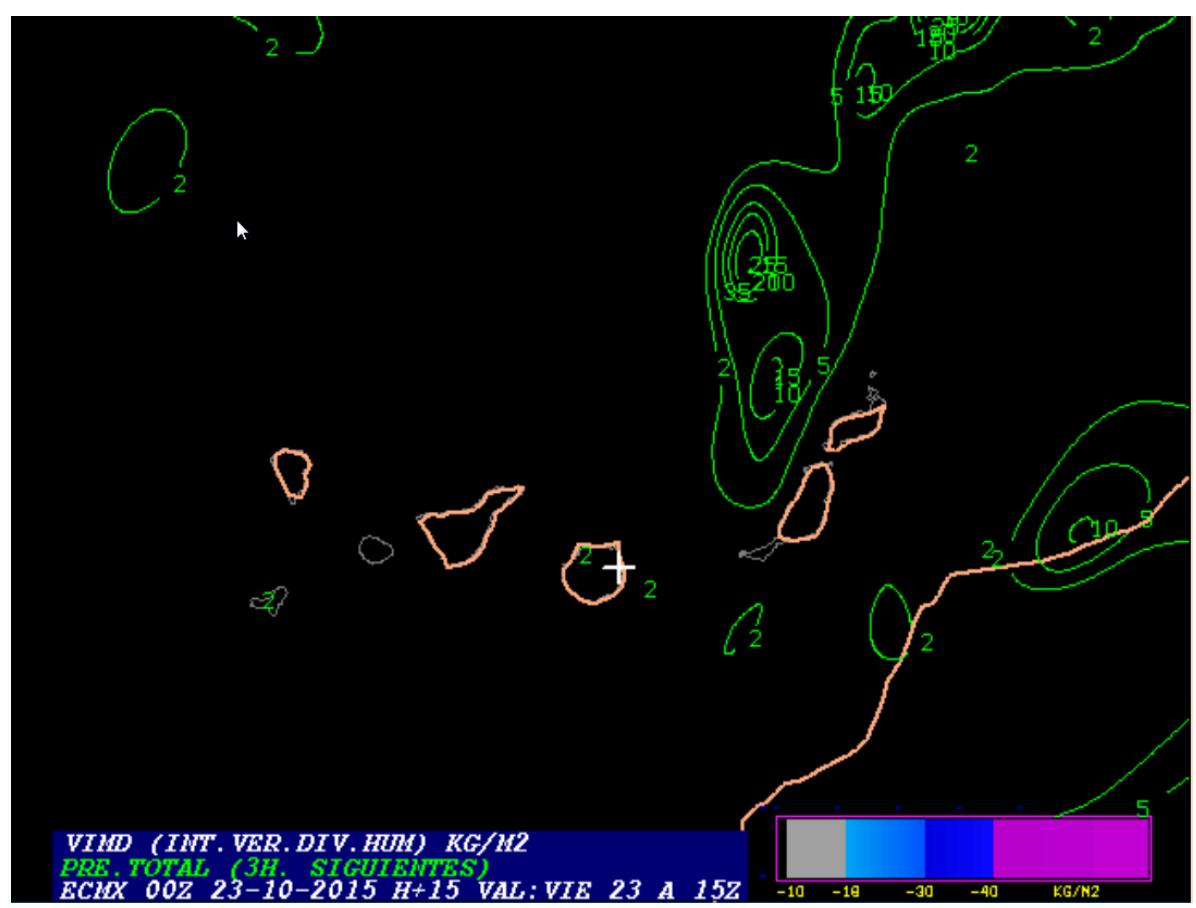

Figura 35: VIMD a las 15 del día 23. 
CHAR Precipitacion ( $\mathrm{mm} / 6 \mathrm{hr})$

23/10/2015 00z H+ 18 Valid: $23 / 10 / 201518 z$

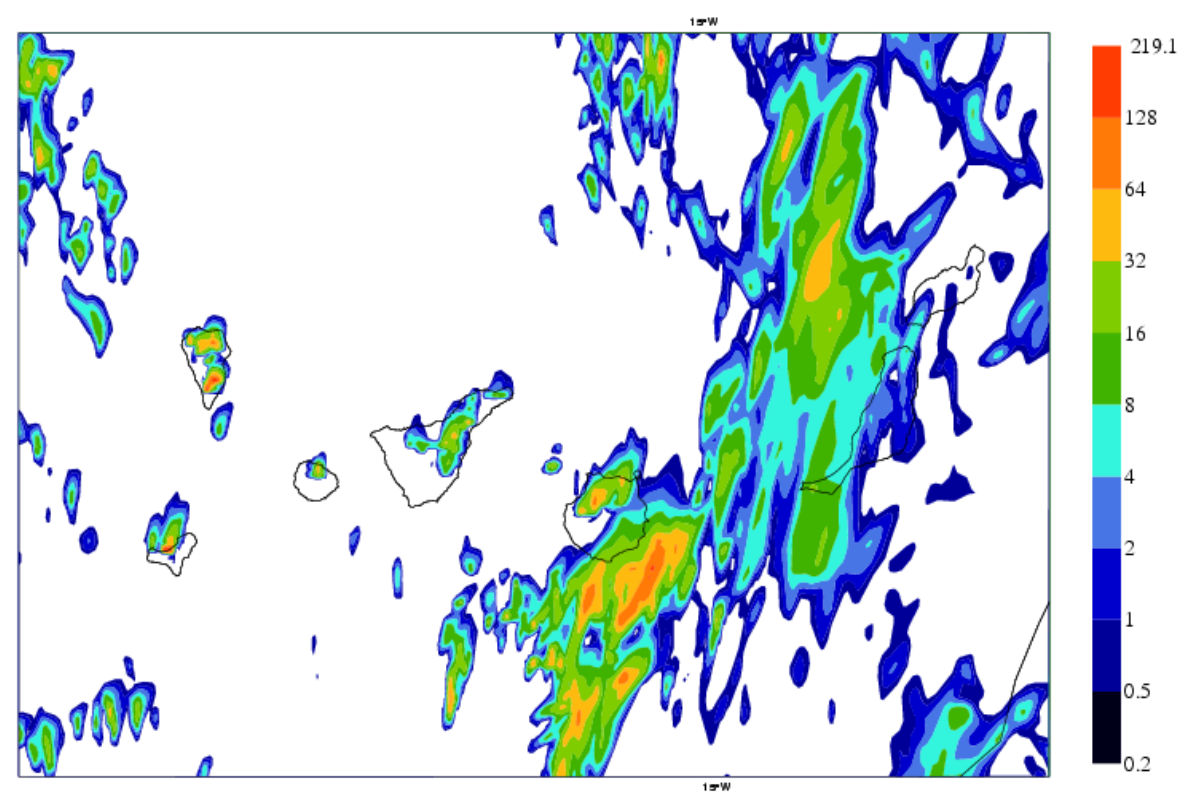

Figura 36: Precipitación acumulada en 6 horas del modelo Harmonie, pasada de las 00, de 12 a 18 horas.

las 12 caería en el problema del spin-up). Desafortundamente, y es algo que se ha comentado entre los predictores, el modelo Harmonie presenta en ocasiones ruido, señales muy significativas que no se sabe si se corresponden con valores reales o son meros outliers. Vemos que para las islas de La Palma o Tenerife el modelo daba importantes valores acumulados que no midieron nuestras estaciones, y que si se dieron debieron de ser muy locales para que ni la red de AEMET ni los colaboradores las detectasen. Hay sospechas de que esos valores realmente tuvieran lugar. Estos registros para La Palma los venía indicando además con varias pasadas de antelación. Es cierto que La Palma quedaba en una zona que sinópticamente era menos activa, pero ello no significa que no pudiera desarrollar convección importante. Si un modelo da unos máximos tan relevantes en una situación tan compleja, es difícil que un predictor/a pueda decir con seguridad que el dato del modelo es falso. Quizá podría haber ayudado en esta situación el hecho de que los máximos "sospechosos"de La Palma parecían relativamente aislados, mientras que el dato de Gran Canaria presentaba mayor extensión espacial. Futuras investigaciones y verificaciones del Harmonie harían falta para apoyar o descartar esta hipótesis. Es difícil concluir algo así sin más estudio puesto que recordemos que precisamente las situaciones de convección son las que presentan máximos en ocasiones muy aislados.

En resumidas cuentas, se puede decir que el Harmonie ubicó relativamente bien la zona de precipitación de interés en los alrededores del municipio de Telde y en el abanico temporal de las horas de la tarde. Acertó de forma bastante aceptable con las cantidades. Sin embargo, indicó también puntos en los que no se obtuvieron esos registros y que se sospecha que pudieran ser solo ruido. 
cHAR Precipitacion ( $\mathrm{mm} / 6 \mathrm{hr}$ )

23/10/2015 06z H+12 Valid: $23 / 10 / 201518 z$

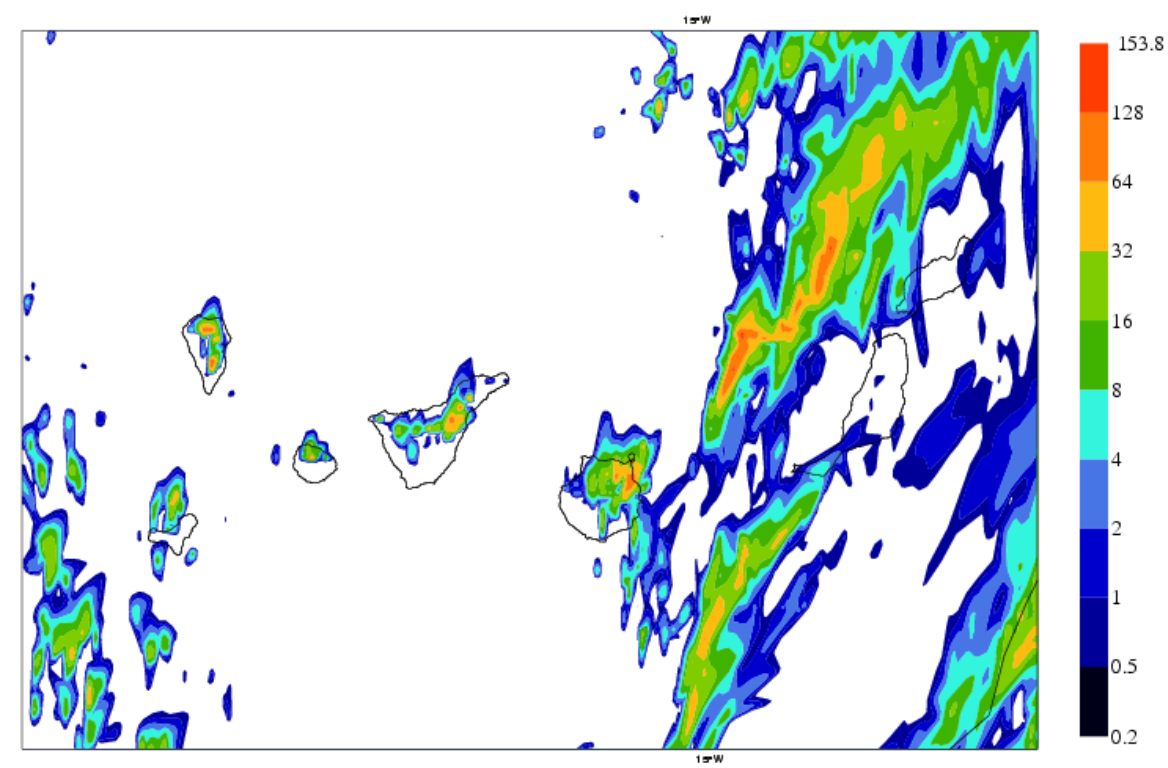

Figura 37: Precipitación acumulada en 6 horas del modelo Harmonie, pasada de las 06, de 12 a 18 horas. 


\section{Conclusiones.}

A lo largo de este estudio hemos analizado la situación de precipitaciones intensas ocurrida durante los días 22 y 23 de octubre de 2015 en las islas Canarias. Estos días las islas estuvieron afectadas por una baja en superficie situada al oeste y con una DANA (día 22) que evolucionó a vaguada durante el día 23. Estas situaciones son sin dudas las que peor tiempo sensible originan en las islas y las que mayor esfuerzo de predicción requieren. Además hubo una entrada de una masa muy húmeda y cálida con origen subtropical que fue trasladándose desde el sur hacia las islas más orientales. Estas situaciones y/o entradas de sur introducen en los modelos numéricos de predicción una alta incertidumbre, convirtiendo la predicción de este tipo de episodios en un reto de suma complejidad.

Los datos registrados demuestran que las precipitaciones no presentan un carácter uniforme, ni siquiera dentro de una misma isla y por tanto existió algún mecanismo junto con la orografía que actuó ayudando a que las lluvias fueran muy eficientes (más 100 litros por metro cuadrado) y provocasen graves percances en varias zonas.

Se analizaron los radiosondeos disponibles (de 00 y 12 UTC) de ambos días, que mostraban un flujo del suroeste aumentando en intensidad con la altura, con una cizalladura vertical unidireccional, y se estudiaron varios parámetros derivados que ayudaron a entender la estructura vertical de la atmósfera durante los dos días del episodio. Se compararon los valores obtenidos de estos parámetros con estudios realizados en Estados Unidos. Sería conveniente realizar más estudios en la zona durante otros eventos severos, para intentar ajustar estos umbrales a nuestra área de interés.

La gran mayoría de las descargas eléctricas se produjeron en el mar, y esto es un factor que dificulta la predicción y emisión de avisos ocasionados por este fenómeno, ya que en muchas ocasiones se pronostican tormentas pero estas no llegan a tierra, siendo muy complicado discernir si una situación con entorno potencialmente favorable para el desarrollo de tormentas afectará o no a la población de las islas. En este caso las islas más afectadas durante el día 22 fueron las occidentales y el día 23 fue Gran Canaria. Los datos muestran cómo en general los focos convectivos asociados a la baja en superficie, DANA y vaguada produjeron una actividad eléctrica generalizada. Llama la atención la poca o nula actividad eléctrica registrada durante la mañana del día 22 en la isla de Gran Canaria, ya que fue durante ese período donde se registraron precipitaciones por encima de los 100 litros por metro cuadrado en cuestióon de unas pocas horas (4 o 5 horas aproximadamente).

Lo más significativo del estudio de las imágenes de radar fue lo acaecido durante el día 22. Se han analizado las diferentes configuraciones y hemos mostrado una estructura lineal que pudiera ser, según el marco teórico, una línea de turbonada que produjo importantes precipitaciones y rachas de viento en la isla de Tenerife.

En cuanto al comportamiento de los modelos, fue una situación que instaba a los predictores a estar pendientes y analizar de forma detallada las herramientas de convección. De forma general se podría decir que el modelo del Centro Europeo para el día 22 pronosticaba dos áreas de interés, una que afectaría a las islas occidentales (por la situación de la baja y la propia DANA) y otra relacionada con la entrada subtropical que afectaría a las islas más orientales, dejando fuera de ambas áreas a Gran Canaria. Si tenemos en consideración los datos registrados a la postre en la zona de Telde se puede considerar que dicho modelo no pronosticó de forma adecuada la situación. Lo ocurrido durante el día 23 fue más predecible y esto quedó reflejado en la antelación de los avisos emitidos desde el GPV. Queda claro que había áreas potenciales para el desarrollo de la convección y precipitaciones fuertes. Sin embargo, como hemos visto hasta ahora, existen forzamientos orográficos (probablemente asociados con convergencias de los flujos) que aumentan la eficacia de las precipitaciones en ciertas zonas; pensamos que en ocasiones los diferentes modelos no captan del todo bien estas situaciones y por ahora esto solo es posible resolverlo con la ayuda de predictores experimentados en esta región. Tal vez no en todas las situaciones sean estas convergencias tan cruciales, pero sí que parecen serlo 
en bastantes casos.

Respecto al Harmonie, el día 22 acertó de forma aproximada con la distribución de la precipitación y con los máximos valores para la parte occidental, aunque infraestimó muchísimo (o directamente, no captó) la precipitación de más de 60 litros en la zona de Telde en Gran Canaria. El día 23 señaló de forma aceptable los máximos de Telde, en Gran Canaria, pero dio unos valores muy altos en la isla de La Palma que no se han podido verificar; si estos datos son mero ruido asociado al modelo o valores reales muy locales y lejos de nuestras estaciones es una cuestión que permanece abierta y a la espera de más estudios sobre este modelo en concreto.

Como trabajo futuro propondríamos varias cuestiones:

- Quizás la de mayor interés, por las consecuencias que genera en las islas, es la de averiguar de manera objetiva qué zonas en según qué situaciones son más favorables a generar precipitaciones súbitas que puedan producir potenciales y repentinas inundaciones. Una tesis doctoral realizada por una compañera predictora [Peñate, 2016] ha sugerido que estos puntos singulares pueden de hecho existir y que Telde podría ser uno de ellos. Si estos posibles puntos singulares están asociados con convergencias de los flujos que realzan la precipitación es también otro tema a investigar.

- Realizar análisis más detallados de los datos radar.

- Generar herramientas y/o estudios de parámetros que estén siempre presentes y que sirvan de ayuda a los predictores de cara a la emisión de avisos de forma objetiva. Por ejemplo, y aunque es un parámetro que apenas se ha empezado a verificar, parece que el "Entorno favorable a convección"generado por el CMT de Málaga captó de forma razonable (aunque mejor el 23 que el 22) la situación de inestabilidad.

- Llevar a cabo estudios para ser capaces de discriminar determinadas señales sospechosas del Harmonie, para saber si se trata de precipitación real o mero ruido.

\section{Agradecimientos.}

Este trabajo no podría haberse realizado sin la valiosísima ayuda de Carlos Jiménez Alonso, del CMT de Málaga, y de Francisco Javier Calvo Sánchez, Jefe de Modelización en Madrid, quienes pusieron a nuestra disposición los datos históricos de los modelos del Centro Europeo y Harmonie, respectivamente. Irene Soledad Peñate De la Rosa, compañera de predicción en el GPV indicó una posible conexión de los datos de precipitación con la existencia de puntos singulares de máximos de lluvia en Canarias que parece interesante.

Agradecemos a Óscar García Colombo y Amelia Arribas Criado, de Servicios Centrales, su apoyo en un par de cuestiones técnicas.

Nuestro agradecimiento a Jesús Alberto Agüera Merino, Delegado Territorial de la AEMET en Canarias, por su apoyo y comprensión.

La Universidad de Wyoming proporcionó los datos de sondeos.

\section{Acrónimos.}

CAPE: Convective Available Potential Energy.

DANA: Depresión Aislada de Niveles Altos.

FIR: Flight Information Region.

FMA: Fenómeno meteorológico adverso.

GPV: Grupo de Predicción y Vigilancia.

NCA: Nivel de Condensación por Ascenso.

NCL: Nivel de Condensación Libre.

NE: Nivel de Equilibrio. 
SBCAPE: Surface Based Convective Available Potential Energy.

\section{Bibliografía.}

\section{Referencias}

[Bunkers et al., 2000]

[Craven, 2000]

[Craven y Brooks, 2004]

[Doswell et al., 1985]

[Elizaga et al., 2003]

[Martín León, 2002]

[Martín et al., 2006]

[Peñate, 2016]

[AEMET, 2016]

[NOAA, 2016]
Matthew. J. Bunkers, Brian Klimowski, Jon. W. Zeitler, Richard. L. Thomson y Morris. L. Weisman, Predicting supercell motion using a new hodograph technique. Weather Forecasting número 10, páginas 61 - 79, 2000.

Jeffrey. P. Craven, A preliminary look at deep layer shear and middle level lapse rates during major tornado out-breaks. Preprints of the 20th Conference on Severe Local Storms, American Meteorological Society, páginas 547 - 550, 2000.

Jeffrey. P. Craven y Harold. E. Brooks, Baseline climatology of sounding derived parameters associated with deep moist convection. National Weather Digest número 28, 2004.

Charles. A. Doswell III, Fernando Caracena y Mark ManGANO, Temporal evolution of 700-500-mb lapse rate as a forecasting tool. A case study. Reprinted from Preprint Volume 14th Conference on Severe Local Storms, October 29 - November 1, Indianapolis, Amer. Met. Soc. páginas 398 - 401, 1985.

F. Elizaga, C. Rus, J. J. Bustos, C. Marrero, R. Sanz, C. Alejo, X. Calbet, P. Rípodas, F. Martín, I. San Ambrosio y P. DEL RÍo, Situación de lluvias torrenciales en Santa Cruz de Tenerife (31 de marzo de 2002). Monografías AEMET/INM, 2003.

Francisco Martín LeÓn, Las gotas frías/DANAs. Ideas y conceptos básicos. Nota Técnica S.T.A.P. número 38, 2001/2002.

F. Martín, J. M. Sánchez-Laulhé, B. Orfila, I. San Ambrosio, J. J. Bustos, V. Quintero y C. Alejo, La tormenta tropical Delta y sus transición extratropical en las cercanías de Canarias. Nota Técnica AEMET, 2006.

Irene Soledad PeÑate De la Rosa, Analysis of the rainfall variability in the subtropical North Atlantic Region: Bermuda, Canary Islands, Madeira and Azores. Tesis Doctoral, Universidad de Las Palmas de Gran Canaria, 2016.

Agencia Estatal de Meteorología, Servicios CliMÁticos, Predicción estacional. http://www.aemet.es/es/ serviciosclimaticos/prediccion_estacional, 2016.

NOAA, National Weather Service Storm Prediction CenTER, Storm Prediction Center. http://www.spc.noaa.gov, 2016. 
[COMET, 2016a]

[COMET, 2016b]
NOAA, UCAR, COMET, Severe Convection II: Mesoscale Convective Systems. https://www.meted.ucar.edu/mesoprim/severe2/ index.htm, 2016

nOAA, UCAR, COMET., Dra. Arlene lang y Dra. JenniLOUISE Evans, Introduction to Tropical Meteorology. http://www. meted.ucar.edu/tropical/textbook_2nd_edition/, 2016 